University of Nebraska - Lincoln

DigitalCommons@University of Nebraska - Lincoln

Insect communities in soybeans of eastern South Dakota: The effects of vegetation management and pesticides on soybean aphids, bean leaf beetles, and their natural enemies

Jonathan G. Lundgren

USDA-ARS, jonathan.lundgren@ars.usda.gov

Louis S. Hesler

USDA-ARS

Sharon A. Clay

South Dakota State University, sharon.clay@sdstate.edu

Scott F. Fausti

South Dakota State University

Follow this and additional works at: https://digitalcommons.unl.edu/usdaarsfacpub

Part of the Agriculture Commons

Lundgren, Jonathan G.; Hesler, Louis S.; Clay, Sharon A.; and Fausti, Scott F., "Insect communities in soybeans of eastern South Dakota: The effects of vegetation management and pesticides on soybean aphids, bean leaf beetles, and their natural enemies" (2013). Publications from USDA-ARS / UNL Faculty. 1164.

https://digitalcommons.unl.edu/usdaarsfacpub/1164

This Article is brought to you for free and open access by the U.S. Department of Agriculture: Agricultural Research Service, Lincoln, Nebraska at DigitalCommons@University of Nebraska - Lincoln. It has been accepted for inclusion in Publications from USDA-ARS / UNL Faculty by an authorized administrator of DigitalCommons@University of Nebraska - Lincoln. 


\title{
Insect communities in soybeans of eastern South Dakota: The effects of vegetation management and pesticides on soybean aphids, bean leaf beetles, and their natural enemies
}

\author{
Jonathan G. Lundgren ${ }^{\mathrm{a}, *}$, Louis S. Hesler ${ }^{\mathrm{a}}$, Sharon A. Clay ${ }^{\mathrm{b}}$, Scott F. Fausti ${ }^{\mathrm{c}}$ \\ ${ }^{a}$ USDA-ARS, North Central Agricultural Research Laboratory (NCARL), 2923 Medary Avenue, Brookings, SD 57006, USA \\ ${ }^{\mathrm{b}}$ Plant Science Department, South Dakota State University, Brookings, SD 57007, USA

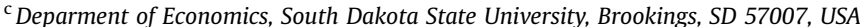

\section{A R T I C L E I N F O}

\section{Article history:}

Received 28 February 2012

Received in revised form

8 August 2012

Accepted 9 August 2012

\section{Keywords:}

Biological control

Cover crop

Integrated pest management

Orius insidiosus

Predator

Systems

Weed

\begin{abstract}
A B S T R A C T
Although most pests of soybeans, Gycine $\max (\mathrm{L}$.$) , in the Northern Great Plains are managed using$ pesticides, farm management practices that encourage biodiversity offer promising long-term, sustainable solutions for controlling insect and weed pests profitably. The recent invasion of the Northern Great Plains by the soybean aphid (Aphis glycines Matsumura; Hemiptera: Aphididae) has had potentially important implications for insect communities in soybeans of this region, although recent descriptions of this regional community are scarce. We describe how three pest management systems that vary in the intensity with which they rely on herbicides and insecticides (chemically intensive, reduced chemical, and spring cover crop treatments) affect insect pest populations, arthropod predator communities, weed assemblages, and soybean yield and profitability. Soybean aphids exceeded economic thresholds in all three years, and insecticides successfully suppressed these outbreaks in the two chemical treatments; aphids exceeded the economic injury level in the cover crop treatment in two of three study years. Bean leaf beetle (Cerotoma trifurcata Forster; Coleoptera: Chrysomelidae) populations were sub-economic in all treatments; insecticides targeting soybean aphid also reduced bean leaf beetles in the first year of study when beetle populations were at their highest. Foliar-dwelling predator populations were substantially higher in the cover crop treatment than in the chemical treatments in all years of study; population declines in the latter treatments were strongly associated with insecticide applications targeting soybean aphids. Foliar predator populations did not rebound within the growing season after insecticides were applied. Soil predator populations were largely unaffected by treatment (except in 2006, when they were more abundant in the cover crop treatment than in the chemical treatments). Weed communities varied among treatments and study years, with few consistent trends except that the chemically intensive treatment had lower weed densities than the other treatments. Although input costs of the cover crop and reduced chemical treatments were lower than the chemically intensive treatment, the chemically intensive treatment was the most profitable of the three. Nevertheless, we contend that the cover crops can be managed more efficiently in order to increase the profitability and competitiveness of this treatment while gaining the long-term benefits gleaned from conserving biodiversity in our agroecosystems.
\end{abstract}

Published by Elsevier Ltd.

\section{Introduction}

The Northern Great Plains lies on the western edge of soybean (Gycine max [L.]) production in North America, and as such harbors a regionally adapted suite of insects and weeds. Soybeans in this

\footnotetext{
* Corresponding author. Tel.: +1 605693 5211; fax: +1 6056935240

E-mail address: Jonathan.Lundgren@ars.usda.gov (J.G. Lundgren).
}

and surrounding regions were largely free from insect pests prior to the introduction of the Asian soybean aphid (Aphis glycines Matsumura [Hemiptera: Aphididae]) (Ragsdale et al., 2004, 2011). Aphid populations rapidly increase during outbreak years (which do not occur every year), alter the physiology of soybean plants, reduce soybean yields, and potentially transmit soybean viruses (Clark and Perry, 2002; Macedo et al., 2003; Riedell and Catangui, 2006; Beckendorf et al., 2008; Riedell et al., 2009). Bean leaf beetle (Cerotoma trifurcata Forster [Coleoptera: Chrysomelidae]) is 
another predominant, but sporadic, pest of soybeans in this region. Adults of this pest defoliate soybean plants and transmit bean pod mottle virus (Mabry et al., 2003; Bradshaw et al., 2008; Byamukama et al., 2011), and larvae consume root nodules of the soybean plant and disrupt its nitrogen dynamics (Lundgren and Riedell, 2008; Riedell et al., 2011). These two pests support a diverse and abundant natural enemy community throughout much of the soybeanproducing region of North America (Toepfer et al., 2009; Ragsdale et al., 2011), but this natural enemy community has been poorly described in the Northern Great Plains (but see Seagraves and Lundgren, 2012 for one report). Although soybeans are commonly produced in the Northern Great Plains (Nebraska, South Dakota and North Dakota were ranked 6th, 8th, and 9th in 2011 soybean hectares harvested; National Agricultural Statistics Service, www. nass.usda.gov), there have been no peer-reviewed, comprehensive studies of insect communities in this crop after the invasion of the soybean aphid. This is particularly important in light of the fact that the introduction of soybean aphid has accompanied a dramatic increase in insecticide use (Ragsdale et al., 2004; Fausti et al., in press), and this undoubtedly has changed the dynamics of insect communities in this region substantially.

Pests are often a symptom of producing crops under monoculture conditions, and efforts to increase the diversity of vegetation within cropland often increase natural enemy populations and reduce pest intensity (Andow, 1991; Tillman et al., 2004; Broad et al., 2009; Lundgren and Fergen, 2010; Letourneau et al., 2011; Lundgren and Fergen, 2011; Koch et al., 2012). Sources of this vegetation diversity may be in the form of low levels of weeds or the use of cover crops or ground covers. In-season ground covers in soybeans can reduce soybean aphid populations, likely through a combination of altered plant quality for pest (soybean aphids and potato leafhopper [Empoasca fabae Harris]) development and augmented populations of natural enemies (Miklasiewicz and Hammond, 2001; Schmidt et al., 2007). But these understory ground covers can also reduce soybean yields to such levels that some researchers concluded that their use is unrealistic for producers (Schmidt et al., 2007). Cover crops do not necessarily have these negative effects on soybean yields (Davis, 2010; Smith et al., 2011). Weed populations provide another source of vegetation diversity that is used by natural enemies of soybean aphids (Griffen and Yeargan, 2002; Lundgren et al., 2009b). The effects of weed presence on soybean aphids has not been well studied, but is likely going to be more important as glyphosate-resistant populations of weeds expand their ranges (Lundgren et al., 2009a; Heap, 2012; Mortensen et al., 2012). Because input costs vary substantially depending on pest management approaches, and insect management decisions are linked to other aspects of crop production, the benefits of vegetation diversity on pest management of soybean insects can only be verified using a systems-level approach that incorporates the relative economic costs and benefits of different best-practice management philosophies.

We used a systems-level approach to examine the relative effects of three soybean production systems on insect and weed communities and soybean profitability at one location over three years in the Northern Great Plains. Specifically, we compared the effects of a cover crop-based system designed to minimize chemical inputs and a system intended to reduce herbicide inputs (and harbor low levels of weeds) with a system reliant on high chemical usage typical of our region. These treatments varied across years and even among plots depending on the prevailing conditions observed at the sites, but were unified through the underlying philosophies that defined the treatments. Although systems-level projects such as these lack the ability to identify clear mechanisms for how specific results are produced within a particular system, this approach provides a 'real world' picture of how these systems will affect key crop production characteristics for endusers. In addition to examining the relative costs and benefits of these different systems, this study represents the most comprehensive recent survey of insect communities of soybeans in the Northern Great Plains published in the peer-reviewed literature.

\section{Methods}

\subsection{Experimental field sites}

Research was conducted in 2005-2007 on the Eastern South Dakota Soil and Water Research Farm, near Brookings, SD (latitude, longitude: 44.348, -96.811). Experimental plots were $24.4 \times 30.5 \mathrm{~m}$ in $2005,12.1 \times 18.3 \mathrm{~m}$ in $2006,18.3 \times 18.3 \mathrm{~m}$ in 2007, and the three treatments were arranged in a RCB design with three replicates in 2005 (nine total plots) and four replicates in 2006 and 2007 (12 total plots). At least $6 \mathrm{~m}$ margins separated the plots; these margins were spring-planted to winter wheat (Triticum aestivum L.) of mixed varieties at $111 \mathrm{~kg} / \mathrm{ha}$. The three treatments examined were 1 ) chemically intensive management, 2) reduced chemical management, and 3) cover crop-based management (each is described more extensively below). Experiments were embedded in a split, 12.5-ha field; the two halves were rotated between corn and soybeans so that half the field was soybeans each year. Soybeans were planted at approximately 370,000 viable seeds per ha on 6-June 2005, 9-June 2006, and 7-June 2007 (using $0.76 \mathrm{~m}$ row spacing). Throughout the experiment, the chemically intensive and reduced chemical systems were planted to soybean variety 91M40 (a glyphosate tolerant variety; Pioneer HiBred, Johnston, IA). The cover crops system was initially planted to $91 \mathrm{M} 40$ in 2005 , but was switched to $91 \mathrm{M} 10$ soybeans in 2006 \& 2007; 91M10 is not glyphosate tolerant, and thus fits within the philosophy of this management system better than the 91M40. The field was under conventional tillage (fall and spring chisel plow), and received $224 \mathrm{~kg} / \mathrm{ha}$ of 14-36-13 (N-P-K; ammonium phosphate) in 2005. In 2006 and 2007, no fertilizer or inoculant was applied. Plots were harvested by combine in mid- to late-October, when grain moisture reached approximately $13 \%$ as measured using a grain moisture tester (DICKEY john Corporation, Auburn, IL). Grain yields were calculated, and grain quality was assessed (\% dry matter, oil, and protein) using a near infrared spectrometer (Foss North America, Eden Prairie, MN). For these grain metrics, three subsamples were taken per plot. Two of the 2007 plots could not be harvested due to high weed pressure (one in the cover-crop based treatment and one in the reduced chemical treatment); yields were considered as zero for these plots, and the data from these plots were excluded from the nutrient analyses. Average maximum seasonal temperatures were 26.11 (2005), 25.00 (2006) and $26.11{ }^{\circ} \mathrm{C}$ (2007), and total precipitation from June 1 to September 30 was 52.37 (2005), 37.13 (2006) and $27.41(2007) \mathrm{cm}$.

\subsection{Chemical intensive system}

This study system is meant to represent conventional production practices of our region. Specifically, pre-emergent herbicide and glyphosate are used to manage weed populations, and insecticides are applied as soybean aphids exceed economic thresholds. At planting in 2005, glyphosate (RoundUp, Monsanto Company, St. Louis, MO) was applied at $4.7 \mathrm{~L}$ (1.66 kg ai) per ha tank-mixed with the pre-emergent herbicide S-metolachlor (Dual Magnum ${ }^{\circledR}$, Syngenta, Greensboro, NC) at $2.3 \mathrm{~L}(2.1 \mathrm{~kg}$ ai) per ha. In 2006, the same rate of glyphosate was applied, but the S-metolachlor (Dual II Magnum, Syngenta) pre-emergent herbicide was applied at $1.2 \mathrm{~L}$ (1.1 kg ai) per ha. In 2007, $2.3 \mathrm{~L}$ (0.83 kg ai) per ha of glyphosate was applied at planting without a pre-emergent herbicide. An 
additional application of glyphosate (1.6 L [0.6 kg ai] per ha) was applied when soybeans were at the V3 stage (July 1, 2005, July 18, 2006, July 6, 2007).

Insecticides were applied to this treatment when soybean aphid populations exceeded the economic threshold of 250 aphids per plant (Ragsdale et al., 2007). This occurred on August 12, 2005 and August 13, 2007. At this point, lambda cyhalothrin (Warrior ${ }^{\circledR}$, Syngenta Corporation) was applied at $0.14 \mathrm{~L}$ [0.011 kg ai] per ha. In 2006, esfenvalerate (Asana ${ }^{\circledR}$ XL, DuPont, Wilmington, DE) was applied at $0.58 \mathrm{~L}(0.04 \mathrm{~kg}$ ai) per ha when aphids initially exceeded the economic threshold (August 7, 2006). Aphids exceeded the economic threshold $7 \mathrm{~d}$ following this spray, and $0.16 \mathrm{~L}(0.012 \mathrm{~kg}$ ai) of lambda cyhalothrin per ha was applied on August 18, 2006.

\subsection{Reduced chemical system}

In this treatment, we reduced the herbicide inputs by only managing weed populations at planting, with an additional input as needed up until the V3 stage of the soybeans (this only occurred in 2005). In all experimental years, glyphosate alone was applied at $4.67 \mathrm{~L}$ (1.66 kg ai) per ha at planting. In 2005, all plots received an additional application of glyphosate (1.61 L [0.6 kg ai] per ha) on July 1 . No additional herbicides were applied to these plots in 2006 or 2007. Insecticides were applied when aphid populations exceeded economic thresholds. No insecticides were applied to this treatment in 2005 as the economic threshold for aphids was only exceeded after the soybean canopy closed, which prohibited tractor application of insecticides. Esfenvalerate (Asana XL, Dupont) was applied at $0.58 \mathrm{~L}(0.04 \mathrm{~kg}$ ai) per ha to two of the plots on August 7, 2006 and lambda cyhalothrin (Warrior, Syngenta) was applied at $0.16 \mathrm{~L}(0.013 \mathrm{~kg} \mathrm{ai})$ per ha to the remaining two plots on August 15, 2006. Lambda cyhalothrin (0.14 L [0.011 kg ai] per ha) was applied to all plots on August 13, 2007.

\subsection{Cover crop-based system}

In this system, a winter cereal cover crop was planted early in the spring prior to planting the soybeans, and was eventually killed. This cover crop replaced additional herbicides and all insecticides in this management system. In 2005 and 2007, winter oat (Avena sativa L.) var. Jerry (IL Foundation Seeds, Champaign, IL) was planted at $77.3 \mathrm{~kg}$ per ha on April 8, 2005 and May 14, 2007. In 2006, winter rye (Secale cereale L.; Millborn Seeds, Brookings, SD) was spring-planted at $127 \mathrm{~kg}$ per ha on May 18. The oat crop was mowed to about $4.5 \mathrm{~cm}$ tall on June 2,2005 and $7.5 \mathrm{~cm}$ on June 16 , 2005 using a flail mower (soybeans were shorter than this cut line). Glyphosate (1.6 L [0.6 kg ai] per ha) was applied to this treatment on July 1,2005 . The rye was mowed using a flail mower on July 6 , 2006; the rye plants were heading and about $1 \mathrm{~m}$ tall. The soybeans were undamaged by the mowing. Herbicide was not applied to this treatment in 2006, and thus the rye persisted throughout the season. In 2005 and 2006, the cover crop was competitive with soybean. Therefore, in 2007 the oat crop was treated with an application of glyphosate ( $2.33 \mathrm{~L}$ [ $0.83 \mathrm{~kg}$ ai] per ha) on June 4 when the soybean crop was planted. Any subsequent benefits were the result of the cover crop residue.

\section{Insect monitoring}

\subsection{Aphid sampling}

Aphids were counted visually on whole plants in the field throughout each growing season. The numbers of sampling dates and plants sampled per date changed according to resources and aphid population sizes. The subsampling system developed by Yoo and O'Neil (2009) was applied in 2006 and 2007 to aphid populations that exceeded the economic injury level (EIL; approximately $694 \pm 95$ aphids per plant [mean $\pm 95 \% \mathrm{CI}$ ], but note that this EIL would be lower when soybean prices exceed $\$ 238$ per metric ton; Ragsdale et al., 2007). The economic threshold (ET), or the aphid population that warrants treatment to avoid exceeding the EIL, is 250 aphids per plant. The scheme involved sampling only the trifoliates on the 1st, 5th, and 9th nodes (from the top), and multiplying the resulting number by 3.76 to attain total aphid populations on the plant. In 2005 , aphids were counted on 12 dates from June 24 to September 8, with sample numbers diminishing as plant size aphid populations increased from 100 plants per plot in June to 6 plants per plot at the end of the season. In 2006, plots were sampled 12 times between June 29 and September 8 with 20 plants per date up to August 11, and 15 plants thereafter. During 2007, 13 samples were taken from June 19 to September 6, with 20 plants per plot on all dates.

\subsection{Tile traps for aphid colonization}

Green tile traps monitored the influx of winged soybean aphids into plots (Hodgson et al., 2005). Individual traps consisted of a collection reservoir ( $3 \mathrm{~cm}$ diameter $\times 5 \mathrm{~cm}$ height) attached to a $1.5 \mathrm{~m}$ tall metal rod. The collection reservoir was composed of a square green tile $(11 \times 11 \mathrm{~cm}$; H \& R Johnson, Stoke-on-Trent, UK) that mimicked the reflectance spectrum of soybean leaves (Irwin and Goodman, 1981). The tile was secured to the bottom half of a clear plastic sandwich box $(11 \times 11 \times 3 \mathrm{~cm})$, which was glued to the lid of a cylindrical plastic canister. One trap was centered in each plot by inserting the metal rod into the ground between soybean rows, and trap height was adjusted equal to the plant canopy height throughout the trapping period (26 June to 27 July 2006, 22 June to 3 August 2007). Trapping was terminated when alatoid offspring of soybean aphids began appearing on soybean plants within the plots. Each trap reservoir received $\sim 200 \mathrm{ml}$ of 1:1 solution of water and ethylene glycol to retain colonizing aphids. Trap contents were emptied every 3-4 d into a jar, and fresh solution was added to the trap reservoir. Alate soybean aphids were identified and tallied for each sample date. Tallies from individual traps were summed across sampling dates prior to data analysis.

\subsection{Sweep samples}

Soybean foliage was swept with a 38-cm diameter net periodically throughout each season from late June (prior to aphid colonization) until the late R6 growth stage ( $\sim$ mid September). In 2005,75 sweeps per plot were collected on each of 10 sample dates (June 24, July 1, 8, 15, 22, August 3, 16, 26, September 2, and 14). In 2006, sweep samples were collected on each of 12 sample days (June 22, 30, July 7, 14, 20, 28, August 4, 14, 21, 29, September 6, and $13,2006)$; twenty sweeps per plot were collected before July 7 , and 60 per plot were collected on June 7 and afterward. In 2007, 75 sweeps per plot were collected on each of 11 sample days (June 26, July 5, 12, 19, 26, August 3, 9, 17, 24, 31, and September 6, 2007). The number of each species per sweep was calculated from these samples.

In all three seasons, the number of Orius insidiosus (Say) (Hemiptera: Anthocoridae), Coccinellidae adults (identified to species), larvae of Coccinellidae, Chrysopidae adults (Chrysoperla spp.), and larvae of Chrysopidae were counted. Additionally, the numbers of bean leaf beetles were recorded in all three years. The number of Geocoris sp. (Hemiptera: Geocoridae) were counted in samples collected after July 14, 2006 (inclusive). Hemerobiidae (Neuroptera) and Nabidae (Hemiptera; likely Nabis americoferus 
Carayon) were added in 2006 and 2007. Spiders (Araneae) and harvestmen (Opiliones: Phalangiidae) were frequently found, but were not recorded from the sweeps.

\subsection{Pitfalls}

Five pitfall traps were established in each plot in a centralized $\times$ pattern. The four lateral traps were $9.0 \mathrm{~m}$ from the central trap in 2005 (6.8 $\mathrm{m}$ in 2006 \& 2007). Each trap consisted of a hole in the ground lined with a PVC tube $(10 \mathrm{~cm}$ diam., approximately $20 \mathrm{~cm}$ deep). To activate the traps, a glass jar $(8 \mathrm{~cm}$ diam., $12 \mathrm{~cm}$ deep) filled with $200 \mathrm{ml}$ of ethylene glycol was placed into each tube; a funnel (openings of 10 and $2 \mathrm{~cm}$ ) was inserted on top of the jar, and the entire assembly was loosely covered with a plywood board $(0.3 \times 0.3 \mathrm{~m})$. Pitfall series were activated for $5 \mathrm{~d}$ at a time. Over the duration of the experiment, seven pitfall series were deployed in 2005 (collected on May 9, May 23, June 22, July 11, August 1, August 19, and September 16), six series were deployed in 2006 (collected on May 30, June 28, July 11, July 25, August 8, August 25), and five series were deployed in 2007 (collected on June 13 , July 3 , July 24 , August 13 , and September 4). After the collection period, samples were returned to the lab, and specimens were washed, cleaned, and identified to the lowest taxonomic position possible. In 2005 , spiders, carabid larvae, chrysopid larvae, predatory hemipterans, lampyrid larvae, and centipedes were not quantified, but they were in subsequent years.

\subsection{Quadrat samples}

Actual densities of surface-dwelling predators were monitored using quadrat samples (Lundgren et al., 2006; Lundgren and Fergen, 2010). A quadrat made of sheet metal $(0.5 \times 0.5 \mathrm{~m} ; 15 \mathrm{~cm}$ tall) was randomly placed within a plot for each sample observation, and the insects found within the top $1 \mathrm{~cm}$ of soil were aspirated. In 2005, we collected three samples per plot on each of nine sample dates (May 6, 9, 23, June 22, July 11, 22, August 1, 19, and September 16). In 2006, two samples were collected from each plot on five sample dates (June 21, July 11, July 25, August 8, and 23). Nocturnal samples were collected (between 22:00 and 2:00) from each plot on July 11-12 (three per plot) and August 8-9 (two per plot), 2006. In 2007, two samples were collected from each plot on five sample dates (June 12, 27, July 11, 26, and August 8). The insects collected were curated and identified to as low a taxonomic level as possible. The mean number of predators per $\mathrm{m}^{2}$ on the soil surface of each plot was extrapolated from these measurements.

\subsection{Weed populations}

Weed species diversity and relative abundance by species were counted along two cross-plot diagonal line transects every $0.5 \mathrm{~m}$. Counts were taken four times in 2005 (at planting, V2, V3, and after canopy closure) and three times in 2006 and 2007 (at planting, V3 growth stage, and after canopy closure). The sampling dates were June 2, June 27, July 11, and 28, 2005; June 6, July 6, and August 31, 2006; and June 7, July 3, and July 18, 2007.

\subsection{Data analysis}

In all analyses, data were analyzed separately for each study year, and data at least approximately conformed to the assumptions of ANOVA. The number of aphids per plant, bean leaf beetles per sweep, predators (per sweep, pitfall trap or $\mathrm{m}^{2}$ quadrat), and weeds per plot were compared among treatments using independent, random, repeated-measures (rm) ANOVAs; all independent variables were considered random effects, and treatment and sample dates were considered fixed effects. The seasonal abundance of alate aphids captured per tile trap, individual predator and weed taxa collected, and the number of weed species collected were compared using independent, random one-way ANOVAs. Statistically different means were separated using LSD means separation tests. All statistics were performed using SYSTAT 11 (SYSTAT Software, Inc., Chicago, IL, 60606).

Data on production input and application methods were used to generate the cost of production estimates. Actual cost data were collected from USDA reports, SDSU extension personnel, and private sector sources. Cost data sources are listed in Appendix 1. An Ordinary Least Squares (OLS) regression analysis was conducted to gain greater insight on treatment and exogenous factors affecting yield variability. Our unit of measure is $\mathrm{kg}$ per ha $\left(Y_{t}\right)$. The data set contains 92 usable observations. We created three bi-variate dummy variables for both year and production method (e.g., one if year is 2005 , zero otherwise or one if cover crop treatment, zero otherwise). The dummy variables are Yr05, Yr07, RECHEM (reduced chemical treatment), and COVER (cover crop treatment). Thus, the base variables are 2006 and traditional chemical treatment. To account for the potential effect of oat being used as the cover crop in years 2005 and 2007, but rye being used in 2006 we created a dummy variable to account for this change (RYE). The regression equation is defined as:

$$
\begin{aligned}
Y_{t}= & \alpha+\beta_{1} \text { RECHEM }_{t}+\beta_{2} \text { COVER }_{t}+\beta_{3} \text { YR0 }_{t}+\beta_{4} \text { YR07 }_{t} \\
& +\beta_{5} \text { RYE }_{t}+U_{t},
\end{aligned}
$$

where $t$ denotes year, $\alpha$ the intercept term, $\beta$ the regression coefficient, and $U_{\mathrm{t}}$ the regression error term. Regression estimates are provided in Table 6 , and diagnostics were conducted to determine if any of the OLS assumptions were violated. It was determined that the regression residuals displayed a heterogeneous pattern that required the application of White's correction procedure for heteroscedasticity (White, 1980). Heteroscedasticity refers to a violation of the OLS assumption of the OLS error term having a constant variance. Failure to correct for this problem results in unreliable standard error estimates.

\section{Results}

\subsection{Pest populations}

Aphid densities varied among management systems and dates each year $(P<0.001$ for all comparisons; Fig. 1$)$, and this is reflected in how quickly aphid populations reached the economic threshold (ET) and economic injury levels (EIL) in these plots. In 2005, the ET was only exceeded on 12-August in the chemically intensive plots, and their numbers were reduced after application of lambdacyhalothrin. The ET was exceeded on 18-August in the reduced and cover crop management systems. No insecticide was applied to either treatment, in the case of reduced chemical management due to canopy closure and in the case of cover crop due to no insecticide decision. The EIL (674 aphids per plant) was exceeded in all plots of the reduced chemical and cover crop treatments on at least one sample date after 25-August. Aphid populations escalated in the cover crop treatment until sampling ceased on 8-September (the EIL was exceeded in all plots after 1-September). In 2006, the ET was exceeded in the chemically intensive and reduced chemical plots on about Aug 6, and remained above the ET until lambdacyhalothrin was applied on 15-August; mean aphid abundance never exceeded the EIL in either of these treatments, and aphids remained well below the ET throughout the season in the cover crop treatment. In 2007, all three management types exceeded the 


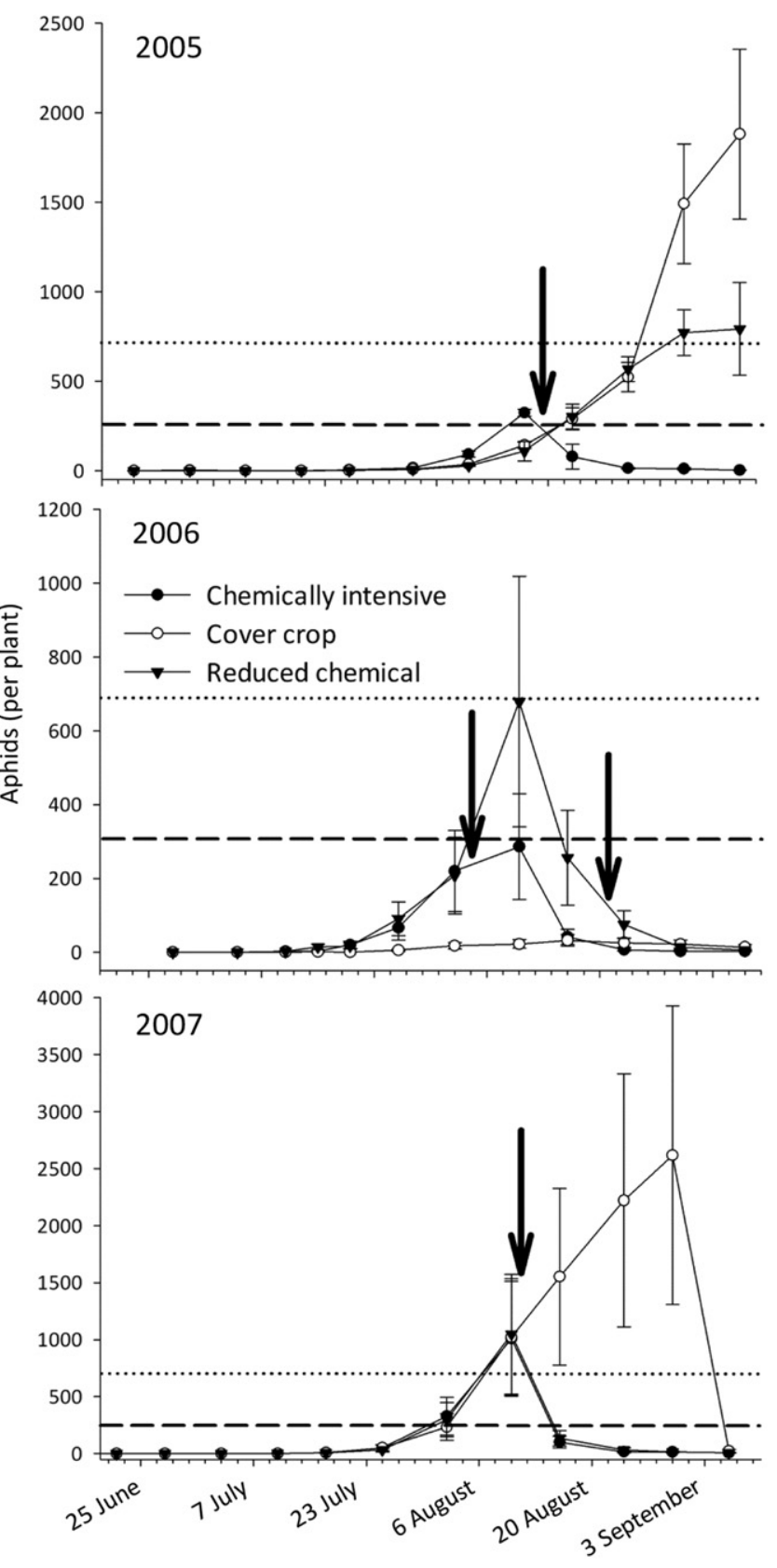

Fig. 1. Soybean aphid population phenology in soybeans produced under three management regimens. Data points represent mean (SEM) aphid numbers per plant per sample plot ( $n=3$ plots in 2005, and 4 in $2006 \& 2007$ ). Short-dashed lines indicate the economic injury level and long-dashed lines indicate the economic threshold for this pest. Arrows indicate dates when insecticides were applied to the chemically intensive (all years) and reduced chemical (only in years $2 \& 3$ ) treatments. Statistical outputs were: 2005 management system: $F_{2,6}=14.42, P=0.008$, time: $F_{11}$, ${ }_{66}=17.14, P<0.001$, treatment $\times$ time: $F_{22}, 66=6.34, P<0.001 .2006$ management system: $F_{2,9}=17.70, P<0.001$, time: $F_{10,90}=12.90, P<0.001$, treatment $\times$ time: $F_{20}$, $90=4.61, P<0.001 .2007$ management system: $F_{2,9}=13.76, P=0.002$, time: $F_{11}$, $99=15.92, P<0.001$, treatment $\times$ time: $F_{22}$, $99=10.58, P<0.001$.

EIL for a single date (August 10). Insecticides in the chemically intensive and reduced chemical management systems reduced the aphid population. In the cover crop treatment, aphids remained above the EIL from August 10 to 30. There were no differences among treatments in the total number of alate aphids recovered from the tile traps in each plot in either year of study (2006 $F_{2}$, $\left.9=0.49, P=0.63 ; 2007: F_{2}, 9=0.47, P=0.64\right)$. Mean (SEM) cumulative alate aphids (pooled across treatments) recovered per plot over the seasons were $36.92 \pm 2.42$ (2006) and $42.92 \pm 4.82$ (2007). Alate aphids only became abundant ( $>2$ per trap) after 20July, 2006 and 24-July, 2007.

There were fewer bean leaf beetles in the chemically intensive treatment in 2005 than in the other treatments (treatment: $F_{2}$, $6=5.27, P=0.048$; date: $F_{9,54}=25.09, P<0.001$; interaction: $F_{18}$, $54=4.13, P<0.001$ ) (Table 1 ). Bean leaf beetle populations were similar among treatments in the subsequent two seasons (Table 1 ) (2006: treatment: $F_{2,9}=0.65, P=0.55$; date: $F_{7,63}=8.35$, $P<0.001$; interaction: $F_{14,63}=3.51, P<0.001 ; 2007$ : treatment: $F_{2}$, $9=0.69, P=0.53$; date: $F_{10}, 90=32.46, P<0.001$; interaction: $F_{20}$, $90=1.70, P<0.001)$. Beetle populations varied over the season, displaying two population peaks over the season as has been previously reported in our region (Hammack et al., 2010; Riedell et al., 2011). There were significant interactions between treatment and sample date in all three years. Population trends over the seasons were similar among treatments in 2005 and 2007 (e.g., all had peaks and troughs on the same sample dates), but they varied in the degree of change over the season (peaks and troughs were more severe in some treatments rather than others). This was also true in 2006, but the cover crop treatment had a large peak in bean leaf beetle populations toward the end of the season that was not present in the other treatments. Seasonal mean \pm SEM numbers of beetles collected per sweep in each treatment year are presented in Table 1.

\subsection{Natural enemy populations}

We discovered an abundant and diverse natural enemy community present in South Dakota soybeans. In sum, 15,378 predators were collected in sweep samples, 18,092 in pitfall samples, and 6688 in quadrat samples over this $3 \mathrm{yr}$ study. At least 17 species (representing five families) were collected in sweep samples, 65 taxa (representing 13 families) in pitfall samples, and 44 taxa (representing 17 families) in quadrat samples (Tables 1-3). Based on our density samples, we estimate that there are about $277,170 \pm 30,283,339,300 \pm 84,100$, and $594,800 \pm 133,300$ predators per ha on the soil surface in the chemical intensive, reduced chemical, and cover crop management systems, respectively. These numbers are within the range of previous estimates of natural enemies in cropland (Lundgren et al., 2006; Lundgren and Fergen, 2010).

The foliar dwelling natural enemy community was reduced by the insecticide applications, but the soil-surface community was unchanged due to treatment. Sweep samples revealed that foliar dwelling arthropods in all three growing seasons were affected by management and sampling date (Table 1, Fig. 2) (2005: treatment: $F_{2,6}=20.78, P=0.002$; date: $F_{9,54}=9.46, P<0.001$; interaction: $F_{18}$, $54=3.61, P<0.001 ; 2006$ : treatment: $F_{2,9}=103.37, P<0.001$; date: $F_{11,99}=32.08, P<0.001$; interaction: $F_{22,99}=9.85, P<0.001 ; 2007$ : treatment: $F_{2,9}=239.08, P<0.001$; date: $F_{10,} 90=64.52, P<0.001$; interaction: $\left.F_{20}, 90=32.68, P<0.001\right)$. Although sample date affected the number of foliar-dwelling natural enemies collected in all three treatments, the significant interaction suggests that this effect was not consistent among treatments (treatment by date interaction $P<0.001$ each year). This is evident from Fig. 2, where natural enemies in the chemically treated systems were reduced after application relative to those in unsprayed treatments. Additional predators that were rarely collected in the sweep samples included several Coccinellidae species: Cycloneda munda (a total of 9 specimens collected), Hippodamia variegata (Goeze) $(n=1)$, Brachyacantha ursina (Fabricius) $(n=8)$ and B. albifrons (Say) $(n=1)$. Natural enemy activity and density on the soil surface was unaffected by treatment, and consistently increased over the field season (Tables 2 and 3) (Pitfall samples: date $P<0.001$ each year; Quadrat 
Table 1

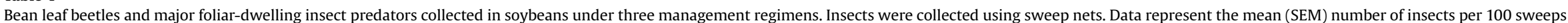

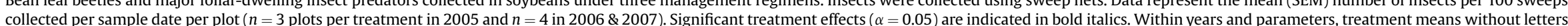

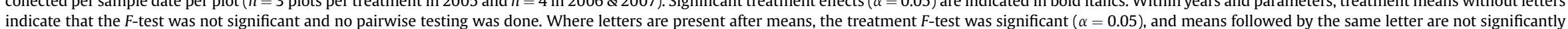
different (LSD multiple comparison test). Additional taxa that were infrequently collected are listed in the results section.

\begin{tabular}{|c|c|c|c|c|c|c|c|c|c|}
\hline & \multicolumn{3}{|l|}{2005} & \multicolumn{3}{|l|}{2006} & \multicolumn{3}{|l|}{2007} \\
\hline & Chemical intensive & Cover crop & Reduced chemical & Chemical intensive & Cover crop & Reduced chemical & Chemical intensive & Cover crop & Reduced chemical \\
\hline \multicolumn{10}{|l|}{ Pests } \\
\hline Cerotoma trifurcata & $6.18 \pm 1.96 a$ & $26.80 \pm 4.55 b$ & $22.84 \pm 6.68 b$ & $1.60 \pm 0.26$ & $2.36 \pm 1.04$ & $1.42 \pm 0.07$ & $3.03 \pm 0.65$ & $2.33 \pm 0.36$ & $2.24 \pm 0.51$ \\
\hline \multicolumn{10}{|l|}{ Natural enemies } \\
\hline $\begin{array}{l}\text { Chrysoperla sp. adult } \\
\text { Col }\end{array}$ & $0.98 \pm 0.27 a$ & $4.49 \pm 0.54 b$ & $1.78 \pm 0.27 a$ & $2.12 \pm 0.24$ & \multicolumn{5}{|c|}{ Neuroptera: Chrysopidae } \\
\hline Chrysoperla sp. larva & $0.27 \pm 0.15 a$ & $1.78 \pm 0.27 b$ & $0.89 \pm 0.09 a$ & $0.69 \pm 0.13$ & $1.18 \pm 0.04$ & $1.25 \pm 0.32$ & $1.76 \pm 0.42$ & $3.58 \pm 0.83$ & $1.48 \pm 0.23$ \\
\hline \multicolumn{10}{|l|}{ Coleoptera: Coccinellidae } \\
\hline Coccinellid larvae & $0.31 \pm 0.09 a$ & $22.68 \pm 7.92 b$ & $10.68 \pm 0.87 a b$ & $4.51 \pm 1.56$ & $2.78 \pm 0.85$ & $4.48 \pm 0.86$ & $7.06 \pm 1.85 a$ & $15.94 \pm 1.89 b$ & $5.55 \pm 0.42 a$ \\
\hline Coccinella septempunctata (L.) & $\mathbf{0 . 0 9} \pm \mathbf{0 . 0 4 a}$ & $0.75 \pm 0.16 b$ & $0.09 \pm 0.09 a$ & $0.21 \pm 0.09$ & $0.35 \pm 0.13$ & $0.28 \pm 0.15$ & $0.73 \pm 0.16 a$ & $2.24 \pm 0.40 b$ & $0.58 \pm 0.12 a$ \\
\hline Coleomegilla maculata De Geer & $0.09 \pm 0.04$ & $2.04 \pm 1.06$ & $1.55 \pm 0.23$ & $0.28 \pm 0.10$ & $0.87 \pm 0.31$ & $0.21 \pm 0.09$ & $0.09 \pm 0.03 a$ & $2.24 \pm 0.38 b$ & $0.52 \pm 0.21 a$ \\
\hline Cycloneda munda (Say) & 0 & 0 & 0 & 0 & 0 & $0.03 \pm 0.03$ & Oa & $0.27 \pm 0.10 b$ & Oa \\
\hline Harmonia axyridis (Pallas) & $1.60 \pm 0.08$ & $16.72 \pm 7.13$ & $9.79 \pm 2.90$ & $0.90 \pm 0.26$ & $3.51 \pm 1.02$ & $2.29 \pm 0.46$ & $1.97 \pm 0.26 a$ & $24.00 \pm 3.03 b$ & $\mathbf{1 . 6 1} \pm \mathbf{0 . 5 2 a}$ \\
\hline Hippodamia convergens Guérin-Méneville & $0.4 \pm 0.34 a$ & $4.71 \pm 0.78 b$ & $0.89 \pm 0.56 a$ & $3.65 \pm 0.26$ & $5.76 \pm 0.70$ & $6.07 \pm 1.13$ & $0.45 \pm 0.06 a$ & $2.85 \pm 0.63 b$ & $0.18 \pm 0.10 a$ \\
\hline Hippodamia parenthesis (Say) & $0.04 \pm 0.04 a$ & $0.57 \pm 0.16 b$ & $0.22 \pm 0.04 a$ & $1.28 \pm 0.15$ & $3.92 \pm 1.34$ & $1.42 \pm 0.35$ & $0.18 \pm 0.03$ & $0.27 \pm 0.10$ & $0.09 \pm 0.06$ \\
\hline Hippodamia tredecempunctata (Say) & Oa & $0.31 \pm 0.04 b$ & $0.04 \pm 0.04 a$ & $0.24 \pm 0.07$ & $0.28 \pm 0.11$ & $0.21 \pm 0.07$ & $0.03 \pm 0.03$ & $0.12 \pm 0.07$ & $0.09 \pm 0.03$ \\
\hline Scymnus rubricaudus (Casey) & $0.27 \pm 0 a$ & $16.40 \pm 3.32 b$ & $1.96 \pm \mathbf{0 . 6 6 a}$ & $0.31 \pm \mathbf{0 . 0 7 a}$ & $7.88 \pm 1.48 b$ & $0.49 \pm 0.12 a$ & $0.15 \pm 0.06$ & $0.33 \pm 0.13$ & $0.09 \pm 0.09$ \\
\hline \multicolumn{10}{|c|}{ Hemiptera: Geocoridae, Nabidae, and Anthocoridae } \\
\hline Geocoris sp. & NA & NA & NA & $1.85 \pm 0.52$ & $12.78 \pm 1.60$ & $2.41 \pm 0.62$ & $1.18 \pm 0.34$ & $1.36 \pm 0.09$ & $1.06 \pm 0.37$ \\
\hline Nabis americoferus Carayon & NA & NA & NA & $14.72 \pm 0.67 a$ & $46.08 \pm 4.35 b$ & $20.42 \pm 1.57 a$ & $14.88 \pm 1.06 a$ & $26.52 \pm 1.74 b$ & $13.36 \pm 0.98 a$ \\
\hline Orius insidiosus (Say) & $3.73 \pm 0.15 c$ & $12.27 \pm \mathbf{0 . 6 8 a}$ & $7.81 \pm 0.79 b$ & $6.08 \pm 0.70 a$ & $15.63 \pm 2.40 b$ & $7.15 \pm 0.52 a$ & $11.51 \pm 0.68 a$ & $35.48 \pm 4.66 b$ & $14.70 \pm 0.87 a$ \\
\hline Total predators & $7.96 \pm 0.25 a$ & $82.73 \pm 13.16 b$ & $35.39 \pm 5.77 a$ & $36.42 \pm 2.79 a$ & $100.45 \pm 4.25 c$ & $48.47 \pm 2.78 b$ & $40.45 \pm 2.56 a$ & $100.23 \pm 2.97 b$ & $39.30 \pm 0.96 a$ \\
\hline
\end{tabular}
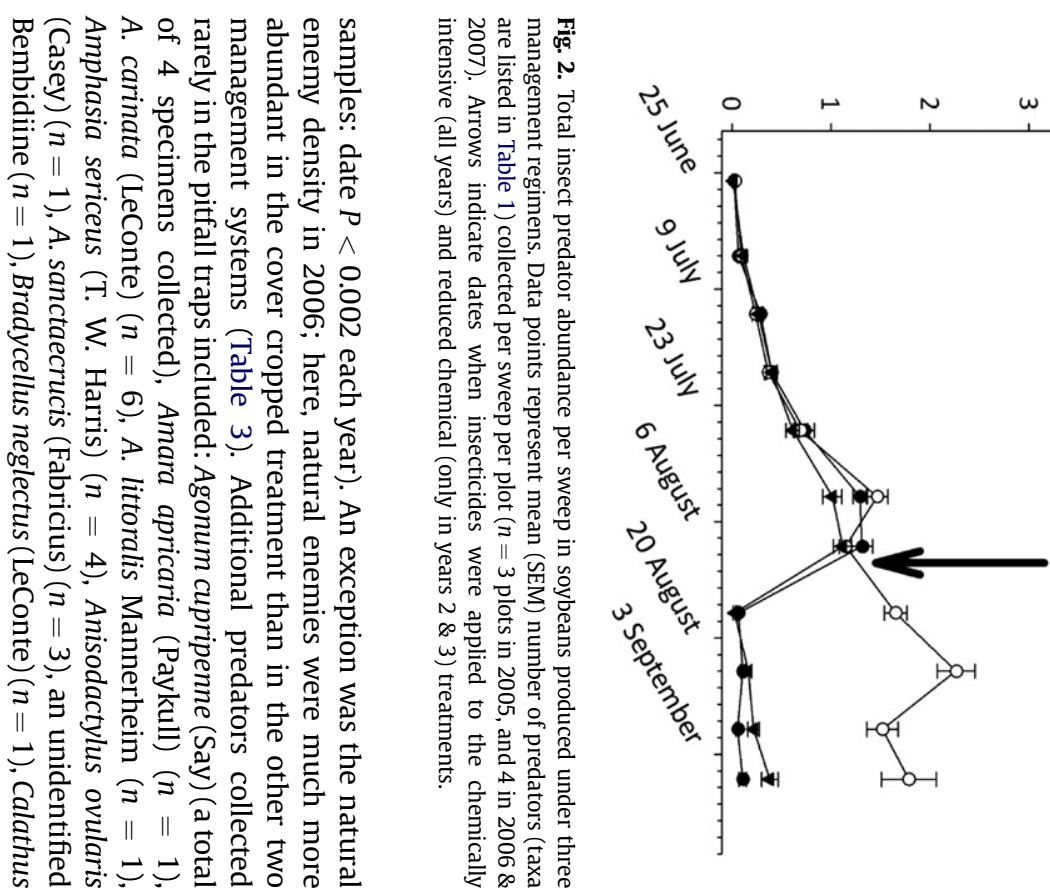

Predators
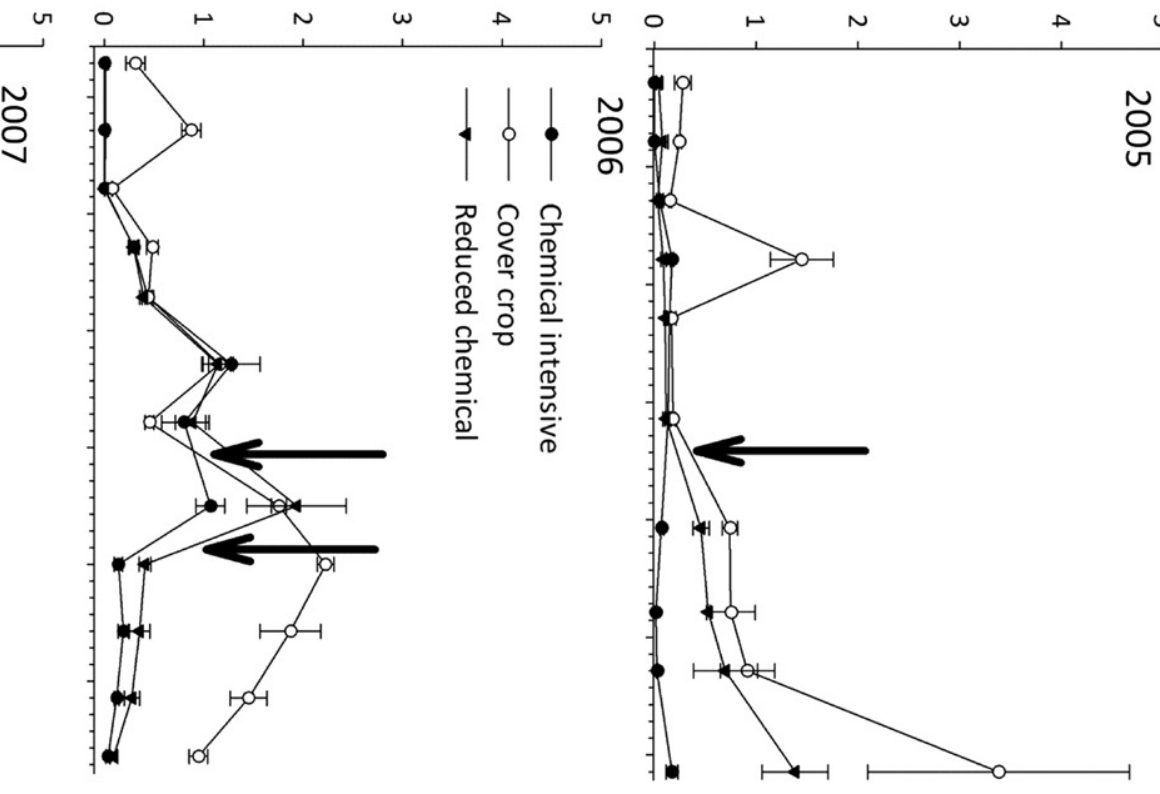
Table 2

The activity densities of major predatory arthropods collected from soybeans managed under three different regimens. Activity densities were estimated using pitfall traps. Data represents the mean (SEM) number of individual taxa collected per trap, per sample period, per plot $(n=3$ plots per treatment in 2005 and $n=4$ in $2006 \& 2007)$. Significant treatment effects $(\alpha=0.05)$ are indicated in bold italics. Within years and parameters, treatment means without letters indicate that the $F$-test was not significant and no pairwise testing was done. Where letters are present after means, the treatment $F$-test was significant $(\alpha=0.05)$, and means followed by the same letter are not significantly different (LSD multiple comparison test). Additional taxa that were infrequently collected are listed in the results section.

\begin{tabular}{|c|c|c|c|c|c|c|c|c|c|}
\hline & \multicolumn{3}{|c|}{2005 (seven sample periods) } & \multicolumn{3}{|c|}{2006 (six sample dates) } & \multicolumn{3}{|c|}{2007 (five sample dates) } \\
\hline & Chemical intensive & Cover crop & Reduced chemical & Chemical intensive & Cover crop & Reduced chemical & Chemical intensive & Cover crop & Reduced chemical \\
\hline \multicolumn{10}{|l|}{ Araneae } \\
\hline Araneae spp. & NA & NA & NA & $3.88 \pm 0.44$ & $10.08 \pm 0.73$ & $14.25 \pm 10.64$ & $2.35 \pm 0.67$ & $3.75 \pm 0.73$ & $3.20 \pm 0.85$ \\
\hline Lycosidae spp. & NA & NA & NA & $0.54 \pm 0.17$ & $0.71 \pm 0.20$ & $1.29 \pm 0.28$ & $0.70 \pm 0.26$ & $0.50 \pm 0.17$ & $0.90 \pm 0.17$ \\
\hline \multicolumn{10}{|l|}{ Chilopoda } \\
\hline Chilopod sp. & NA & NA & NA & $0.50 \pm 0.22$ & $0.29 \pm 0.10$ & $0.58 \pm 0.26$ & $0.40 \pm 0.24$ & $0.55 \pm 0.36$ & $0.90 \pm 0.37$ \\
\hline \multicolumn{10}{|l|}{ Coleoptera: Carabidae } \\
\hline Coleoptera larvae $^{\mathrm{a}}$ & NA & NA & NA & $0.25 \pm 0.11$ & $0.13 \pm 0.13$ & $0.25 \pm 0.08$ & $0.30 \pm 0.13$ & $0.25 \pm 0.10$ & $0.35 \pm 0.10$ \\
\hline Agonum placidum (Say) & $0.81 \pm 0.22$ & $0.19 \pm 0.06$ & $0.29 \pm 0.11$ & $1.58 \pm 0.56$ & $2.67 \pm 0.82$ & $1.38 \pm 0.64$ & $8.35 \pm 0.69$ & $9.70 \pm 1.73$ & $11.45 \pm 2.15$ \\
\hline Bembidion quadrimaculatum oppositum (Say) & $0.05 \pm 0.05$ & $0.05 \pm 0.05$ & $0.05 \pm 0.05$ & $0.29 \pm 0.13$ & $0.46 \pm 0.08$ & $0.08 \pm 0.08$ & $0.05 \pm 0.05$ & 0 & $0.15 \pm 0.10$ \\
\hline Bembidion rapidum (Leconte) & 0 & $0.05 \pm 0.05$ & 0 & $0.17 \pm 0.07$ & $0.21 \pm 0.16$ & 0 & $0.10 \pm 0.10$ & $0.20 \pm 0.08$ & $0.10 \pm 0.10$ \\
\hline Brachinus ovipennis LeConte & $0.29 \pm 0.08$ & $1.76 \pm 0.55$ & $0.67 \pm 0.39$ & $0.54 \pm 0.86$ & $0.08 \pm 0.7$ & $0.33 \pm 0.20$ & $0.75 \pm 0.13$ & $1.00 \pm 0.18$ & $0.95 \pm 0.17$ \\
\hline Cyclotrachelus alternans (Casey) & $5.81 \pm 1.40$ & $13.43 \pm 5.08$ & $9.10 \pm 2.20$ & $6.92 \pm 1.34$ & $4.79 \pm 0.66$ & $9.00 \pm 2.22$ & $8.80 \pm 1.00$ & $8.80 \pm 1.28$ & $9.10 \pm 0.44$ \\
\hline Elaphropus sp. & $0.10 \pm 0.10$ & $0.05 \pm 0.05$ & $0.29 \pm 0.14$ & $1.13 \pm 0.57 a$ & $2.79 \pm 0.26 b$ & $\mathbf{1 . 0 8} \pm \mathbf{0 . 4 9 a}$ & $0.65 \pm 0.32$ & $1.70 \pm 0.44$ & $2.25 \pm 0.88$ \\
\hline Harpalus pensylvanicus (DeGeer) & 0 & $0.05 \pm 0.05$ & $0.10 \pm 0.10$ & $0.71 \pm 0.28$ & $0.13 \pm 0.08$ & $0.33 \pm 0.15$ & $0.15 \pm 0.10$ & $0.40 \pm 0.14$ & $0.40 \pm 0.14$ \\
\hline Poecilus chalcites (Say) & $3.33 \pm 1.93$ & $3.24 \pm 0.34$ & $7.05 \pm 0.10$ & $0.50 \pm 0.30$ & $0.21 \pm 0.04$ & $0.67 \pm 0.32$ & $2.00 \pm 0.76$ & $2.50 \pm 0.56$ & $1.90 \pm 0.49$ \\
\hline Poecilus lucublandus lucublandus (Say) & $2.71 \pm 1.30$ & $3.14 \pm 1.09$ & $2.33 \pm 0.88$ & $2.71 \pm 1.13$ & $1.25 \pm 0.28$ & $3.04 \pm 0.49$ & $0.75 \pm 0.30$ & $1.15 \pm 0.28$ & $0.7 \pm 0.17$ \\
\hline Pterostichus permundus (Say) & $2.62 \pm 0.52$ & $2.05 \pm 0.37$ & $1.48 \pm 0.70$ & $1.58 \pm 0.26$ & $1.71 \pm 0.56$ & $1.58 \pm 0.43$ & $9.15 \pm 1.56$ & $8.95 \pm 1.30$ & $6.10 \pm 0.70$ \\
\hline Scarites quadriceps Chaudoir & $0.52 \pm 0.17 b$ & $2.10 \pm 0.64 a b$ & $2.90 \pm 0.62 a$ & $1.04 \pm 0.23$ & $0.79 \pm 0.10$ & $0.79 \pm 0.21$ & $2.10 \pm 0.35$ & $2.30 \pm 0.47$ & $1.80 \pm 0.85$ \\
\hline \multicolumn{10}{|l|}{ Coleoptera: Coccinellidae } \\
\hline Coccinellid spp. & $0.14 \pm 0.08$ & $0.57 \pm 0.44$ & 0 & $0.29 \pm 0.20 a$ & $1.25 \pm 0.38 b$ & $0.29 \pm 0.13 a$ & $0.05 \pm 0.05$ & $0.10 \pm 0.10$ & $0.10 \pm 0.10$ \\
\hline Coccinellid larvae & 0 & $0.05 \pm 0.05$ & $0.10 \pm 0.10$ & $0.38 \pm 0.10$ & $4.71 \pm 2.58$ & $0.33 \pm 0.12$ & 0 & $0.10 \pm 0.06$ & $0.05 \pm 0.05$ \\
\hline \multicolumn{10}{|l|}{ Coleoptera: Staphylinidae } \\
\hline $\begin{array}{l}\text { Staphylinid spp. } \\
\text { Hymenoptera: Formicidae }\end{array}$ & $6.95 \pm 2.02$ & $9.05 \pm 2.19$ & $6.76 \pm 1.53$ & $10.08 \pm 0.55$ & $10.29 \pm 1.38$ & $8.58 \pm 2.08$ & $1.95 \pm 0.30$ & $2.95 \pm 1.48$ & $1.85 \pm 0.96$ \\
\hline Formicid spp. & $0.67 \pm 0.21$ & $0.52 \pm 0.33$ & $0.10 \pm 0.05$ & $14.00 \pm 8.83$ & $20.04 \pm 5.56$ & $17.71 \pm 10.43$ & $14.50 \pm 5.13$ & $8.30 \pm 2.14$ & $19.40 \pm 2.05$ \\
\hline \multicolumn{10}{|l|}{ Opiliones: Phalangiidae } \\
\hline \multicolumn{7}{|l|}{ Orthoptera: Gryllidae } & & & $23.00 \pm 1.61$ \\
\hline Allonemobius sp. & $1.86 \pm 0.66$ & $2.10 \pm 0.56$ & $4.09 \pm 1.29$ & $10.25 \pm 1.91$ & $8.00 \pm 1.24$ & $7.75 \pm 1.05$ & $21.80 \pm 5.25$ & $19.85 \pm 4.14$ & $23.35 \pm 6.21$ \\
\hline Gryllus pennsylvanicus Burmeister & $8.48 \pm 1.39$ & $3.95 \pm 0.27$ & $17.43 \pm 5.36$ & $6.79 \pm 1.79$ & $7.50 \pm 0.78$ & $6.75 \pm 1.86$ & $16.70 \pm 4.86$ & $14.45 \pm 3.28$ & $17.25 \pm 4.95$ \\
\hline Total predators & $63.62 \pm 11.75$ & $65.38 \pm 6.48$ & $81.33 \pm 5.48$ & $88.83 \pm 9.94$ & $93.25 \pm 8.52$ & $95.83 \pm 10.25$ & $114.45 \pm 17.88$ & $108.20 \pm 9.12$ & $127.60 \pm 7.80$ \\
\hline
\end{tabular}

a Although these larvae were not identified to family, the vast majority belonged to unknown Carabidae species. 
Table 3

The density $\left(\right.$ per $\left.\mathrm{m}^{2}\right)$ of major predatory arthropods collected on the soil surface in soybean fields managed under three regimens. Densities were obtained by hand collections of specimens from metal quadrats. Data represent the mean (SEM) number of taxa collected per sample date per plot ( $n=3$ plots per treatment in 2005 and $n=4$ in $2006 \& 2007)$. Significant treatment effects $(\alpha=0.05)$ are indicated in bold italics. Within years and parameters, treatment means without letters indicate that the $F$-test was not significant and no pairwise testing was done. Where letters are present after means, the treatment $F$-test was significant $(\alpha=0.05)$, and means followed by the same letter are not significantly different (LSD multiple comparison test). Additional taxa that were infrequently collected are listed in the results section.

\begin{tabular}{|c|c|c|c|c|c|c|c|c|c|}
\hline & \multicolumn{3}{|l|}{2005} & \multicolumn{3}{|l|}{2006} & \multicolumn{3}{|l|}{2007} \\
\hline & Chemical intensive & Cover crop & Reduced chemical & Chemical intensive & Cover crop & Reduced chemical & Chemical intensive & Cover crop & Reduced chemical \\
\hline \multicolumn{10}{|l|}{ Araneae } \\
\hline Araneae spp. & $6.86 \pm 1.65$ & $13.19 \pm 3.94$ & $7.21 \pm 1.51$ & $2.55 \pm 0.33$ & $13.64 \pm 1.41$ & $21.24 \pm 17.78$ & $6.10 \pm 0.30$ & $4.40 \pm 0.54$ & $4.30 \pm 01.33$ \\
\hline $\begin{array}{l}\text { Chilopod sp. } \\
\text { Coleoptera: Carabidae }\end{array}$ & $0.05 \pm 0.05$ & $0.05 \pm 0.05$ & $0.30 \pm 0.15$ & $0.64 \pm 0.21$ & $0.71 \pm 0.30$ & $0.36 \pm 0.14$ & $0.30 \pm 0.19$ & $0.20 \pm 0.12$ & $0.50 \pm 0.25$ \\
\hline Carabid larvae & $0.40 \pm 0.20$ & $0.44 \pm 0.23$ & $0.64 \pm 0.27$ & $0.36 \pm 0.07 a$ & $3.38 \pm 1.06 b$ & $1.21 \pm 0.21 a$ & $0.10 \pm 0.10$ & $0.10 \pm 0.12$ & $0.10 \pm 0.10$ \\
\hline Agonum placidum & 0 & 0 & 0 & $0.21 \pm 0.14$ & $0.64 \pm 0.30$ & $0.14 \pm 0.08$ & 0 & $0.20 \pm 0.20$ & 0 \\
\hline $\begin{array}{l}\text { Bembidion quadrimaculatum } \\
\text { oppositum }\end{array}$ & $0.10 \pm 0.05$ & $0.10 \pm 0.05$ & $0.10 \pm 0.05$ & $0.26 \pm 0.15$ & $1.45 \pm 0.57$ & $0.71 \pm 0.14$ & $0.20 \pm 0.12$ & $0.20 \pm 0.20$ & $0.10 \pm 0.10$ \\
\hline Bembidion rapidum & 0 & 0 & 0 & $0.14 \pm 0.08$ & $1.52 \pm 1.04$ & $0.29 \pm 0.12$ & $0.20 \pm 0.12$ & $0.10 \pm 0.10$ & $0.10 \pm 0.10$ \\
\hline Elaphropus spp. & 0 & 0 & 0 & $6.52 \pm 0.54$ & $6.16 \pm 2.17$ & $7.95 \pm 2.08$ & 0 & 0 & 0 \\
\hline Microlestes linearis (LeConte) & 0 & 0 & 0 & $0.90 \pm 0.39 a$ & $1.57 \pm 0.29 b$ & $0.50 \pm 0.27 a$ & 0 & $0.20 \pm 0.12$ & $0.10 \pm 0.10$ \\
\hline Stenolophus sp. & 0 & 0 & 0 & Oa & $0.21 \pm 0.07 b$ & Oa & 0 & 0 & 0 \\
\hline \multicolumn{10}{|l|}{ Coleoptera: Coccinellidae } \\
\hline Coccinellid larvae & 0 & $0.20 \pm 0.05$ & $0.15 \pm 0.15$ & $0.29 \pm 0.16$ & $1.00 \pm 0.25$ & $1.00 \pm 0.43$ & $1.10 \pm 0.30$ & $1.40 \pm 0.81$ & $0.40 \pm 0.16$ \\
\hline Coccinella septempunctata & 0 & 0 & 0 & 0 & $0.21 \pm 0.14$ & $0.14 \pm 0.08$ & 0 & $0.10 \pm 0.10$ & $0.30 \pm 0.10$ \\
\hline Harmonia axyridis & 0 & 0 & 0 & $0.14 \pm 0.08 a$ & Oa & $0.43 \pm 0.08 b$ & $0.10 \pm 0.10$ & $0.10 \pm 0.10$ & $0.10 \pm 0.10$ \\
\hline Hippodamia convergens & 0 & 0 & 0 & $0.29 \pm 0.12$ & $0.57 \pm 0.20$ & $0.50 \pm 0.24$ & 0 & 0 & 0 \\
\hline $\begin{array}{l}\text { Scymnus rubricaudus } \\
\text { Coleoptera: Staphylinidae }\end{array}$ & $\boldsymbol{O a}$ & $1.38 \pm 0.56 b$ & $0.05 \pm 0.05 a$ & $0.14 \pm 0.08 a$ & $12.69 \pm 2.91 b$ & $0.07 \pm 0.07 a$ & 0 & 0 & 0 \\
\hline \multirow{2}{*}{\multicolumn{10}{|c|}{ Hemiptera: Geocoridae, Nabidae, and Anthocoridae }} \\
\hline Geocoris spp. & 0 & $0.10 \pm 0.10$ & $0.20 \pm 0.20$ & $4.29 \pm 3.15 a$ & $33.21 \pm 2.28 b$ & $0.62 \pm 0.13 a$ & $0.90 \pm 0.10$ & $1.10 \pm 0.38$ & \\
\hline Nabis americoferus & $0.25 \pm 0.13$ & $0.15 \pm 0.09$ & $0.05 \pm 0.05$ & $2.36 \pm 1.12 a$ & $9.40 \pm 1.11 b$ & $1.57 \pm 0.55 a$ & $1.00 \pm 0.42$ & $0.90 \pm 0.10$ & $1.20 \pm 0.23$ \\
\hline $\begin{array}{l}\text { Orius insidiosus } \\
\text { Hymenoptera: Formicidae }\end{array}$ & $0.05 \pm 0.05$ & $0.15 \pm 0$ & $0.25 \pm 0.13$ & $0.36 \pm 0.14 a$ & $4.02 \pm 0.40 b$ & $1.93 \pm 0.77 a$ & $0.70 \pm 0.30$ & $0.50 \pm 0.25$ & $0.70 \pm 0.10$ \\
\hline $\begin{array}{l}\text { Formicid spp. } \\
\text { Neuroptera: Chrysopidae }\end{array}$ & $10.17 \pm 3.60$ & $2.52 \pm 0.51$ & $4.49 \pm 0.35$ & $2.36 \pm 0.79 a$ & $7.52 \pm 0.49 b$ & $2.76 \pm 1.10 a$ & $2.40 \pm 1.28$ & $3.10 \pm 1.31$ & $2.70 \pm 1.39$ \\
\hline $\begin{array}{l}\text { Chrysoperla larvae } \\
\text { Opiliones: Phalangiidae }\end{array}$ & $0.05 \pm 0.05 a$ & $0.69 \pm 0.18 b$ & $0.20 \pm 0.13 a$ & $0.21 \pm 0.07 a$ & $0.14 \pm 0.08 a$ & $0.57 \pm 0.12 b$ & $0.50 \pm 0.30$ & $0.20 \pm 0.12$ & $0.10 \pm 0.10$ \\
\hline $\begin{array}{l}\text { Phalangium opilio } \\
\text { Orthoptera: Gryllidae }\end{array}$ & $1.19 \pm 0.34$ & $0.84 \pm 0.30$ & $1.83 \pm 0.27$ & $1.98 \pm 0.29$ & $5.29 \pm 0.71$ & $5.00 \pm 1.46$ & $3.50 \pm 0.74$ & $2.50 \pm 1.05$ & $3.60 \pm 1.61$ \\
\hline Allonemobius spp. & $0.15 \pm 0.09$ & 0 & $0.44 \pm 0.30$ & $0.50 \pm 0.34$ & $1.36 \pm 0.37$ & $0.52 \pm 0.10$ & $0.80 \pm 0.28$ & $0.20 \pm 0.12$ & $0.70 \pm 0.10$ \\
\hline Gryllus pennsylvanicus & $0.69 \pm 0.34$ & $0.05 \pm 0.05$ & $0.25 \pm 0.43$ & $0.31 \pm 0.13$ & $0.48 \pm 0.18$ & $0.21 \pm 0.21$ & $0.40 \pm 0.16$ & $0.50 \pm 0.10$ & $0.60 \pm 0.26$ \\
\hline Total predators & $24.10 \pm 6.21$ & $26.17 \pm 5.62$ & $22.77 \pm 4.09$ & $26.05 \pm 4.55 a$ & $113.14 \pm 9.88 b$ & $49.02 \pm 22.25 a$ & $32.10 \pm 5.79$ & $30.80 \pm 1.67$ & $27.20 \pm 4.79$ \\
\hline
\end{tabular}


gregarius (Say) $(n=5)$, Carabus serratus Say $(n=1)$, Chlaenius platyderus Chaudoir $(n=1), C$. sericeus (Forster) $(n=2), C$. tomentosus (Say) $(n=1)$, Cicindela punctulata Olivier $(n=8)$, Clivina bipustulata (Fabricius) $(n=1)$, Clivina impressefrons LeConte $(n=13)$, Cymindus neglectus Haldeman $(n=1), C$. pilosus Say $(n=2)$, Discoderus parallelus (Haldeman) $(n=1)$, Galerita janus (Fabricius) $(n=1)$, Harpalus caliginosus (Fabricius) $(n=18)$, H. compar LeConte $(n=1)$, H. faunus Say $(n=2), H$. herbivagus Say $(n=9), H$. reversus Casey $(n=1)$, Loricera pilicornis (Fabricius) $(n=3)$, Microlestes linearis $(n=11)$, Notiophilus sp. $(n=3)$, Platynus decentis (Say) $(n=1)$, Pterostichus femoralis (Kirby) $(n=14), P$. melanarius (Illiger) $(n=1)$, Scarites subterraneus Fabricius $(n=11)$, and Stenolophus comma (Fabricius) $(n=14)$ (Coleoptera: Carabidae); Coleomegilla maculata $(n=4)$, Hippodamia convergens $(n=2)$, Hippodamia parenthesis $(n=4)$, H. tredecimpunctata $(n=1)$, and Harmonia axyridis $(n=1)$ (Coleoptera: Coccinellidae); Lampyridae larvae $(n=2)$ (Coleoptera); Geocoris sp. $(n=2)$ (Hemiptera: Geocoridae) and N. americoferus $(n=11)$ (Hemiptera: Nabidae); and Chrysoperla larvae $(n=7)$ (Neuroptera: Chrysopidae). In the quadrat samples, several infrequently collected taxa were : An unidentified Bembidiine $(n=1)$, Calleida decora (Fabricius) $(n=1), C$. impressefrons $(n=8)$; Colliuris pennsylvanica (L.) $(n=1)$, Cyclotrachelus alternans $(n=1)$, Harpalus pensylvanicus $(n=1)$, Harpalus sp. $(n=1)$, Lebia solea Hentz $(n=1)$, $L$. pilicornis $(n=1)$, Notiophilus sp. $(n=1)$, Poecilus lucublandus $(n=1)$, Pterostichus permundus $(n=1)$, (Coleoptera: Carabidae); C. maculata $(n=4), H$. parenthesis $(n=6)$, and $H$. tredecimpunctata $(n=6)$ (Coleoptera: Coccinellidae); Lampyridae larvae $(n=10)$ and an adult $(n=1)$ (Coleoptera); Reduviidae sp. $(n=1)$ (Hemiptera); and Hemerobiid sp. adult ( $n=3$ ) (Neuroptera: Hemerobiidae).

Although there were differences in individual predator taxa among the systems (Tables 1-3), there were few consistent trends among years in the responses of specific species to treatments. $O$. insidiosus and Scymnus rubricaudus were consistently highest in the cover cropped treatment across all three years of study (this latter species was only significantly so in the first two years of study) (Table 1). Chrysoperla adults and larvae and coccinellid larvae were higher in the cover cropped treatment in years when oat was planted, but not when rye was planted (Table 1 ).

\subsection{Weed populations}

More than 20 weed taxonomic groups were present over the study. Two amaranths, redroot pigweed and common waterhemp (Amaranthus retroflexus and $A$. rudis, respectively) and common lambsquarters (Chenopodium album) were the most abundant species observed throughout the study (although these species were notably fewer in 2006 than in other years) (Table 4). Similar numbers of weed species were found among treatments, although significantly fewer weed species were recovered in $2006(P=0.01)$ than in the other sample years (treatment: $F_{2}, 24=0.96, P=0.40$; year $F_{2}$, $24=6.03, P=0.01$, interaction: $F_{4,24}=0.73, P=0.58$ ). Mean (SEM) species numbers per plot (pooled across years) were $5.36 \pm 0.80$, $6.27 \pm 0.73,6.18 \pm 0.85$ in the chemically intensive, cover crop, and reduced chemical management systems, respectively.

The numbers of weeds counted along the transects differed among treatments in only one of the three study years (Table 4 ). The seasonal patterns of weed community phenologies differed among treatments (2005: treatment: $F_{2,6}=2.11, P=0.20$; date: $F_{3,18}=7.00$, $P=0.003$; interaction: $F_{6,18}=4.94, P=0.004 ; 2006$ : treatment: $F_{2}$, $8=4.67, P=0.045$; date: $F_{2}, 16=12.75, P<0.001$; interaction: $F_{4}$, $16=7.91, P=0.001 ; 2007$ : treatment: $F_{2,9}=2.05, P=0.18$; date: $F_{2}$, $18=2.03, P=0.16$; interaction: $\left.F_{4,18}=8.67, P<0.001\right)$. In 2005 , the seasonal weed count was similar among treatments, although count varied among the sample periods; also, there was a significant interaction between treatment and sample period (Table 4). This variability among treatments occurred during the period prior to canopy closure, but after herbicide application to the chemically intensive treatment. Here, weed populations in the reducedchemical treatment were more abundant than the other treatments (Fig. 3). In 2006, more weeds were counted along the transects in the cover crop treatment than the other two treatments with more weeds present after soybean canopy closure in the cover cropped system (Fig. 3, Table 4). In 2007, there were no season-long differences in weed abundance among management systems, nor was there an effect of sample period on weed abundance. However, after soybean canopy closure, there were more weeds counted in the reduced chemical treatment relative to the chemically intensive treatment (Fig. 3, Table 4).

\subsection{Yields, grain quality, and system profitability}

Yield was greatest in 2005, averaging about $9000 \mathrm{~kg}$ per ha, and least in 2007, averaging about $2500 \mathrm{~kg}$ per ha. A 6-wk drought beginning on June 15 reduced yields in 2007 relative to the first two study years. Yield differences among the management systems were only observed in 2006, where yields in the treatments were ranked as reduced chemical $=$ chemical intensive $>$ cover crop; in 2006, the rye cover crop reduced yield by more than $50 \%$. Management also affected soybean quality. Soybean from the cover crop treatment had lower oil content but greater protein content than at least one of the two chemical treatments in 2006 and 2007. In 2005, grain in the cover crop management system had reduced protein content compared with the other two management regimes (Table 5).

Ordinary Least Squares regression procedure was used to investigate the relationship between yield and treatment. Production cost and yield per ha revenue estimates across treatments are presented in Table 5 . The global $F$-test for overall model significance had a $P<0.001$ (Table 6 ). The regression model has an adjusted $R^{2}=0.64$, indicating that $64 \%$ of the variability in yield was explained by the statistical model. All of the regression coefficients $(\beta \mathrm{s})$ were statistically significant at the $5 \%$ level or lower. Regression results indicate that there is a $0.24 \mathrm{t}$ per ha difference between chemically intensive and reduced chemical treatments, and a $0.68 \mathrm{t}$ per ha difference between chemically intensive and cover crop treatments. The beta coefficient for the "RYE" variable is -1.25 . Again, this variable captures the unique effect that rye had when it was used as a cover crop. Using oat as a cover crop increased yields by $0.96 \mathrm{t}$ per ha relative to the rye cover crop. Furthermore, while the use of a cover crop reduced yield in this study, it also reduced input costs.

Production cost data indicate that the cover crop treatment component with conventional seed had the lowest average cost of production per ha. Yield data indicate the cover crop treatment component also produced the lowest yields relative to the chemically intensive and reduced chemical alternatives. In the studied system, the lower cost structure associated with the cover crop treatment was not large enough to overcome the market value of reduced yield, although the profitability of this system increased as the study went on alongside our experience with this production system. This notwithstanding, the cover crop treatment underperformed the alternatives with respect to profit (Table 5).

\section{Discussion}

The soybean production systems in this study had dramatic effects on both insect and weed communities. Although efforts to reduce pesticide inputs increased beneficial species and reduced the costs of production, the profitability of the treatments receiving pesticides (chemical intensive and reduced chemical) exceeded the cover crop treatment. In the first two years of study (Table 5), the 
Table 4

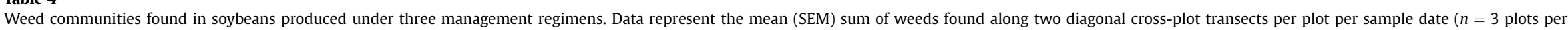

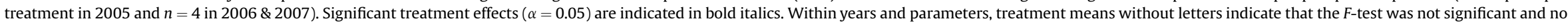

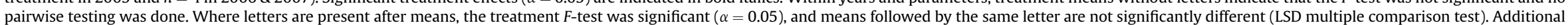
taxa that were infrequently collected are listed in the results section.

\begin{tabular}{|c|c|c|c|c|c|c|c|c|c|c|}
\hline \multirow[t]{2}{*}{ Species } & \multirow[t]{2}{*}{ Common name } & \multicolumn{3}{|l|}{2005} & \multicolumn{3}{|l|}{2006} & \multicolumn{3}{|l|}{2007} \\
\hline & & $\begin{array}{l}\text { Chemical } \\
\text { intensive }\end{array}$ & Cover crop & $\begin{array}{l}\text { Reduced } \\
\text { chemical }\end{array}$ & $\begin{array}{l}\text { Chemical } \\
\text { intensive }\end{array}$ & Cover crop & $\begin{array}{l}\text { Reduced } \\
\text { chemical }\end{array}$ & $\begin{array}{l}\text { Chemical } \\
\text { intensive }\end{array}$ & Cover crop & $\begin{array}{l}\text { Reduced } \\
\text { chemical }\end{array}$ \\
\hline Amaranthus sp. & $\begin{array}{l}\text { Redroot pigweed \& } \\
\text { common } \\
\text { waterhemp }\end{array}$ & $1.13 \pm 1.03$ & $0.65 \pm 0.53$ & $2.23 \pm 1.12$ & $0.06 \pm 0.06$ & $0.08 \pm 0.05$ & $0.08 \pm 0.08$ & $4.94 \pm 1.12$ & $7.11 \pm 2.23$ & $15.03 \pm 5.75$ \\
\hline Chenopodium album $\mathrm{L}$. & Common lambsquarters & $0.13 \pm 0.04 a$ & $0.19 \pm 0.04 a$ & $1.65 \pm 0.54 b$ & $0.36 \pm 0.21$ & $0.92 \pm 0.70$ & $0.47 \pm 0.25$ & $2.25 \pm 0.67$ & $1.89 \pm 0.63$ & $4.97 \pm 2.57$ \\
\hline Helianthus sp. & Wild sunflower & $0.29 \pm 0.06$ & $0.25 \pm 0.11$ & $0.36 \pm 0.27$ & $0.47 \pm 0.27$ & $2.25 \pm 1.20$ & $0.39 \pm 0.22$ & 0 & $0.11 \pm 0.08$ & $0.11 \pm 0.05$ \\
\hline Malva neglecta Wallr. & Common mallow & $0.13 \pm 0.10$ & $0.40 \pm 0.33$ & 0 & 0 & 0 & 0 & $0.08 \pm 0.05$ & $0.03 \pm 0.03$ & $0.28 \pm 0.13$ \\
\hline Acer sp. & Maple seedling & 0 & $0.11 \pm 0.11$ & $0.40 \pm 0.31$ & $0.03 \pm 0.03$ & 0 & $0.03 \pm 0.03$ & 0 & 0 & 0 \\
\hline Trifolium repens $\mathrm{L}$. & White clover & $0.15 \pm 0.09$ & $0.08 \pm 0.06$ & $0.06 \pm 0.06$ & 0 & 0 & 0 & $0.03 \pm 0.03$ & $0.03 \pm 0.083$ & 0 \\
\hline Zea mays $\mathrm{L}$. & Volunteer corn & 0 & 0 & 0 & 0 & $0.14 \pm 0.08$ & $0.06 \pm 0.06$ & $0.11 \pm 0.05$ & $0.11 \pm 0.08$ & $0.17 \pm 0.11$ \\
\hline Poaceae spp. & Unidentified grasses & $0.11 \pm 0.08$ & 0 & $0.17 \pm 0.09$ & $0.03 \pm 0.03$ & $0.11 \pm 0.05$ & $0.08 \pm 0.05$ & $0.11 \pm 0.06 a$ & $0.81 \pm 0.18 \mathrm{~b}$ & $0.08 \pm 0.08 \mathrm{a}$ \\
\hline Polygonum convolvulus $\mathrm{L}$. & Wild buckwheat & $0.02 \pm 0.02$ & $0.02 \pm 0.02$ & $0.15 \pm 0.15$ & $0.03 \pm 0.03$ & $0.06 \pm 0.06$ & 0 & $0.06 \pm 0.06$ & 0 & $0.06 \pm 0.06$ \\
\hline Cirsium spp. & $\begin{array}{l}\text { Unidentified thistle } \\
\text { species }\end{array}$ & $0.06 \pm 0.04$ & $0.02 \pm 0.02$ & $0.08 \pm 0.02$ & 0 & 0 & 0 & $0.03 \pm 0.03$ & 0 & 0 \\
\hline $\begin{array}{l}\text { Solanum ptychanthum } \\
\text { Dunal.ex DC. }\end{array}$ & Eastern blacknightshade & 0 & $0.02 \pm 0.02$ & $0.13 \pm 0.07$ & $0.08 \pm 0.08$ & $0.11 \pm 0.05$ & $0.33 \pm 0.10$ & 0 & $0.06 \pm 0.03$ & $0.06 \pm 0.06$ \\
\hline Oxalis dillenii Jacq. & Gray-green woodsorrel & 0 & $0.06 \pm 0.04$ & $0.06 \pm 0.06$ & 0 & $0.03 \pm 0.03$ & 0 & $0.25 \pm 0.08 \mathrm{~b}$ & 0a & $0.14 \pm 0.05 \mathrm{ab}$ \\
\hline Thlaspi arvense L. & Field pennycress & $0.04 \pm 0.02$ & 0 & $0.08 \pm 0.08$ & 0 & 0 & 0 & 0 & 0 & $0.06 \pm 0.03$ \\
\hline Datura stramonium L. & Jimsonweed & $0.02 \pm 0.02$ & 0 & $0.02 \pm 0.02$ & 0 & 0 & 0 & 0 & 0 & 0 \\
\hline Portulaca oleracea L. & Common purselane & 0 & $0.02 \pm 0.02$ & $0.02 \pm 0.02$ & 0 & 0 & $0.03 \pm 0.03$ & $0.03 \pm 0.03$ & $0.14 \pm 0.14$ & $0.17 \pm 0.03$ \\
\hline Solanum rostratum Dunal & Buffalobur & 0 & 0 & $0.082 \pm 0.02$ & 0 & 0 & 0 & 0 & 0 & 0 \\
\hline $\begin{array}{l}\text { Polygonum arenastrum } \\
\text { Jord. Ex Boreau }\end{array}$ & Common knotweed & 0 & $0.02 \pm 0.02$ & 0 & 0 & 0 & 0 & 0 & 0 & 0 \\
\hline Ambrosia artemisiifolia $\mathrm{L}$. & Common ragweed & 0 & 0 & 0 & 0 & $0.03 \pm 0.03$ & 0 & 0 & 0 & 0 \\
\hline $\begin{array}{l}\text { Taraxacum officinale } \\
\text { G.H. Weber ex Wiggers }\end{array}$ & Dandelion & 0 & 0 & 0 & 0 & $0.03 \pm 0.03$ & $0.03 \pm 0.03$ & $0.14 \pm 0.11$ & $0.08 \pm 0.05$ & $0.25 \pm 0.07$ \\
\hline $\begin{array}{l}\text { Brassica kaber (DC.) } \\
\text { L.C. Wheeler }\end{array}$ & Wild mustard & 0 & 0 & 0 & $0.08 \pm 0.08$ & $0.03 \pm 0.03$ & $0.06 \pm 0.06$ & 0 & 0 & 0 \\
\hline Unidentified seedling & & $0.27 \pm 0.18$ & $0.31 \pm 0.11$ & $0.52 \pm 0.25$ & $0.06 \pm 0.03$ & $0.11 \pm 0.05$ & $0.06 \pm 0.03$ & $0.17 \pm 0.03 a$ & $0.39 \pm 0.10 \mathrm{~b}$ & $0.08 \pm 0.03 a$ \\
\hline Unknown sp. & & $0.02 \pm 0.02$ & $0.02 \pm 0.02$ & 0 & $0.03 \pm 0.03$ & 0 & $0.06 \pm 0.06$ & 0 & 0 & 0 \\
\hline Total weeds & & $2.36 \pm 1.33$ & $2.17 \pm 1.13$ & $5.94 \pm 1.84$ & $1.22 \pm 0.53 a$ & $3.89 \pm 0.83 b$ & $1.67 \pm \mathbf{0 . 0 5 a}$ & $8.19 \pm 1.44$ & $10.78 \pm 2.87$ & $21.47 \pm 7.87$ \\
\hline
\end{tabular}



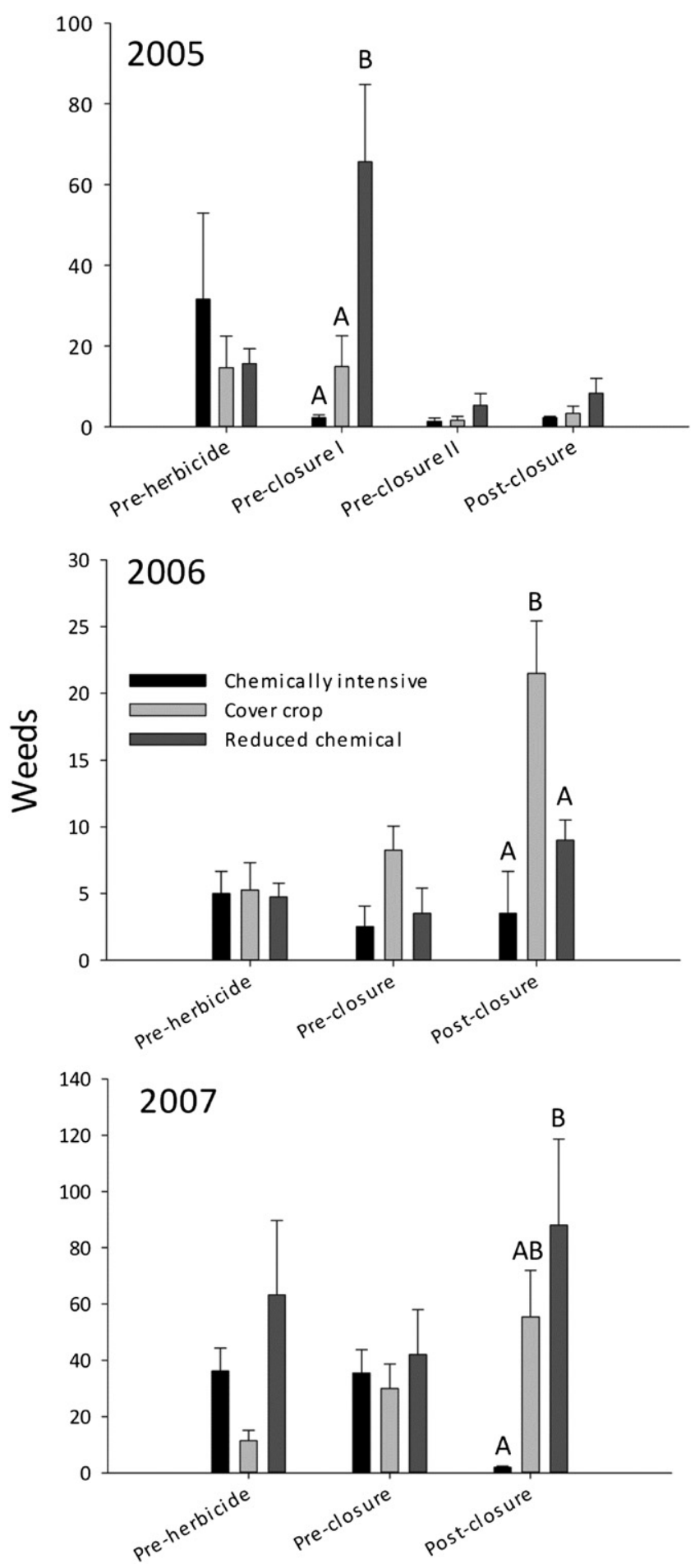

Fig. 3. Weed seasonal dynamics in soybeans produced under three management regimens. Weed populations were measured every $0.5 \mathrm{~m}$ along two $32 \mathrm{~m}$ transects in each plot ( $n=3$ in 2005, 4 in 2006 \& 2007). Populations were recorded prior to herbicide applications, after herbicide applications but prior to soybean canopy closure, and after canopy closure. In 2005, an additional observation was recorded after herbicides were applied to the chemically intensive treatment, but before herbicides were sprayed in the reduced chemical treatment. Bars represent mean (SEM) weed number per plot, and bars capped with different letters are significantly different $(\alpha=0.05)$. chemically intensive and reduced chemical treatments had very similar profits, indicating that reducing herbicide inputs to a single application before canopy closure was sufficient for managing typical weed pressure. In 2007, one plot in each of the reduced chemical and cover cropped treatments had extraordinary weed seed input (the farmer had fed cows in this area of the field) that could only be overcome with more intensive herbicide use; the other reduced chemical plots had equivalent yields to the chemical intensive treatment in 2007 (see footnote in Table 5). There were several deficiencies (discussed below) in our management of the cover crop treatment that made this the least profitable of the three systems. If additional revenue could be added to this cover crop production system, either through gaining organic certification of the grain or through reducing the impact of the cover crop on yields, growers could take advantage of the lower costs of production and favorable habitats provided by this treatment to create more sustainable, long-term solutions for pest management.

Soybean aphid populations differed among the treatments, with insecticide applications having the greatest influence on relative aphid populations (Fig. 1). In all three seasons, a single application of lambda cyhalothrin (but not esfenvalerate) was sufficient to reduce mounting aphid infestations below 250 per plant for the remainder of the season. When the oat cover crop was removed from the field early in the season (2005 \& 2007), aphid populations exceeded the EIL in all plots by season's end. When the rye cover crop was allowed to persist throughout the season, aphid populations were kept below 50 aphids per plant throughout the season. This same pattern was observed with the ground cover in Schmidt et al. (2007); in this case, an alfalfa living mulch ground cover was allowed to persist in the understory of the soybean crop, and aphid populations were diminished as a result. But also like Schmidt et al. (2007), we found that when the rye was allowed to persist season-long, yields of soybean were significantly reduced by approximately 67\% (Table 5), making this strategy unappealing for farmers. In a recent survey of organic soybeans preceded by winter rye cover crops, Koch et al. (2012) found that aphids were reduced through cover-cropping and yields were unaffected by the cover crop, but in this study yields were exceptionally low even in the untreated control ( $<1.35 \mathrm{t}$ per ha). Finally, incorporating wheat into soybeans as an intercrop successfully reduced potato leafhopper, while having no effects on soybean yield (Hammond and Jeffers, 1990; Miklasiewicz and Hammond, 2001). All of this taken together suggests that cover crops and ground covers have potential for reducing soybean aphids, but care must be taken to ensure that the cover crop is managed in ways that maximize soybean yields.

Bean leaf beetle populations differed among management systems, but only during the first year of study when the pest was particularly abundant (Table 2). The first study year experienced beetle populations that were 10 -fold higher in the reduced chemical and cover crop systems than in 2006 and 2007 (representing a 7-year high for this research site). Numbers remained between 10 and 100 beetles (per 100 sweeps) from July 22 until August 26, 2005, which corresponds to the adult stage of the 1st generation (i.e. the progeny of the overwintering generation) of this pest in eastern South Dakota (Hammack et al., 2010; Riedell et al., 2011). Yield correlations for this pest based on sweeps suggest that these populations did not approach economically damaging levels in the reduced chemical and cover crop treatments in 2005 (Hammack et al., 2010). Aphid-targeted insecticide inputs in the chemical treatment had the added benefit of reducing bean leaf beetle populations in 2005; this benefit of insecticides targeted at other, more serious insect pests of soybeans is found in other regions as well (Johnson et al., 2008; Musser et al., 2012). In summary, bean leaf beetle populations are affected by insecticides that target 


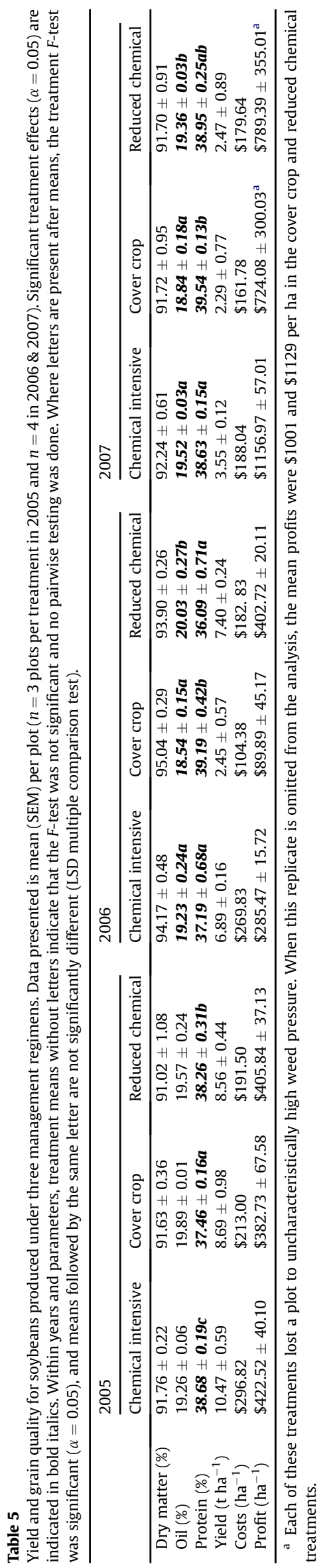

Table 6

Regression analysis of effect of three pest management systems (chemically intensive, reduced chemical, and cover crop) on soybean yields over a three year, replicated experiment.

\begin{tabular}{|c|c|c|c|c|}
\hline \multicolumn{5}{|c|}{ Dependent variable: soybean yield ( $t$ per ha) } \\
\hline Mean & 2.86 & \multicolumn{2}{|c|}{ Obs. } & 92 \\
\hline SSR & 56,53 & \multicolumn{2}{|c|}{ Mean SSR } & 11.30 \\
\hline SSE & 28.57 & \multicolumn{2}{|c|}{ Mean SSE } & 0.33 \\
\hline F & 34.03 & \multicolumn{2}{|c|}{$P<0.001$} & \\
\hline$R^{2}$ & 0.66 & \multicolumn{2}{|c|}{ Adj $R^{2}=0.64$} & \\
\hline \multicolumn{2}{|c|}{ Independent variables: } & Coefficient & Std. Error & T-stat. \\
\hline \multicolumn{2}{|c|}{ Constant } & 2.71 & 0.08 & 33.77 \\
\hline \multicolumn{2}{|c|}{ Reduced chemical } & -0.24 & 0.12 & -1.97 \\
\hline \multicolumn{2}{|c|}{ Cover crop } & -0.68 & 0.20 & -3.44 \\
\hline \multicolumn{2}{|c|}{ Year 3} & 0.91 & 0.14 & 6.35 \\
\hline \multicolumn{2}{|c|}{ Year 1} & 0.82 & 0.11 & 7.24 \\
\hline \multicolumn{2}{|c|}{ RYE } & -1.25 & 0.24 & -5.23 \\
\hline
\end{tabular}

soybean aphids, but bean leaf beetle populations were not economically threatening even when insecticides were relaxed and vegetation was diversified by weeds or cover crops.

A diverse natural enemy community was discovered in soybeans of the Northern Great Plains, but only the foliar-dwelling predator community differed among the management systems (Tables $1-3$, Fig. 2). Predators are commonly shown to be an important factor suppressing soybean aphid population growth (Fox et al., 2004; Rutledge et al., 2004; Desneux et al., 2006; Brosius et al., 2007; Rhainds et al., 2007; Schmidt et al., 2007; Costamagna et al., 2008). Over the 3 yr study, we collected at least 83 species of predators; this number would have increased if we had identified the Formicidae, Staphylinidae and Araneae to species level. Foliar predator communities vary depending on the region of study, and their relative abundance and community composition may have changed since the invasion of the soybean aphid (Schmidt et al., 2008). In Canada, Michigan, and Iowa, the main predators found in association with soybean aphids are coccinellids (Rhainds et al., 2007; Costamagna et al., 2008; Schmidt et al., 2008), often dominated by $H$. axyridis later in the growing season (Rutledge et al., 2004). But natural enemy communities in the Northern Great Plains (NE and SD) are dominated by 0 . insidiosus (Anthocoridae), N. americoferus (Nabidae), and spiders (Brosius et al., 2007; Seagraves and Lundgren, 2012). The current work substantiates that while coccinellids were a consistent presence in our fields (especially $H$. axyridis late in the season), predatory hemipterans $(O$. insidiosus and $N$. americoferus) dominated the predator guild living in the soybean foliage (but note that we did not describe the spider community in this study). At least $O$. insidiosus is regarded as one of the primary predators of the soybean aphid, especially in delaying early season build-up of aphid populations and reducing smaller aphid populations (Rutledge and O'Neil, 2005; Desneux et al., 2006; Costamagna et al., 2008). With these observations, it is difficult to say which of the predators are having the greatest impact on aphid populations, but in numerical terms our work echoes previous studies that $O$. insidiosus and $H$. axyridis are likely important, and underscores that $N$. americoferus is on the list of potentially important biological control agents of soybean aphid. The soil surface in soybeans has a diverse community of predators throughout the soybean producing region, often reportedly dominated by spiders and carabid beetles (Rutledge et al., 2004; Gardiner et al., 2010). Our work suggests that this may be an artifact of the choice of sampling procedure. We do not deny that carabids and spiders are an important and diverse component of the natural enemy guild, but our data suggest that their predominance is likely overinflated due to pitfall sampling. We used pitfall traps to capture dozens of carabid species in soybeans (Table 2 and Results Section), 
although spiders were not as abundant in our systems as in surveys from other regions (Gardiner et al., 2010). However, when we examined actual densities of predators, carabid beetles were much less abundant than spiders, ants, and harvestmen in our systems (Table 3). These observations on actual densities of predators are supportive of other reports involving quadrat samples (Lundgren et al., 2006; Lundgren and Fergen, 2010). Regardless, employing multiple sample methods helps give a better understanding of predator diversity within soybeans of the Northern Great Plains.

The foliar-dwelling predator community was the only one affected by the management treatments. This observation may have resulted because there was more prey present in the cover cropped treatment and because insecticides likely reduced predator populations in the chemical treatments. Other work has shown that insecticide use in soybeans (Ohnesorg et al., 2009; Seagraves and Lundgren, 2012) and other crops (Marvier et al., 2007; Wolfenbarger et al., 2008) can reduce some or all natural enemy species present within a habitat. $O$. insidiosus and $S$. rubricaudus were consistently more abundant in the cover crop system than in the other two management systems (Table 1). O. insidiosus is an important predator of soybean thrips and the soybean aphid (Brosius et al., 2007; Butler and O'Neil, 2008; Desneux and O'Neil, 2008; Harwood et al., 2009). This omnivorous bug also has strong preferences for specific plant species as oviposition sites, and increased vegetation diversity has been shown to increase O. insidiosus populations (Lundgren et al., 2008, 2009b; Seagraves and Lundgren, 2010). Insecticides aimed at aphid management also adversely affect $\mathbf{O}$. insidiosus (Seagraves and Lundgren, 2012). We believe that the provision of preferred non-crop vegetation and possibly food diversity, as well as reduced insecticide use, in large part explain the increased numbers of $O$. insidiosus in the cover crop system. Very little is known about the natural history of S. rubricaudus, but the total predator population peaks observed in the cover crop system in late June to early July of 2005 and 2006 were the result of mass emergence of S. rubricaudus adults (Fig. 2). The congeners $S$. louisianae J. Chapin and S. babai Sasaji have been identified as predators of soybean aphids in Kentucky and Asia, respectively (Brown et al., 2003; Liu et al., 2004). We have consistently captured this predator in field plots of eastern South Dakota that were preceded by a spring grass cover crop (Lundgren and Fergen, 2010), and identify this species as meriting further attention from the perspective of pest management.

Weed phenology was affected by management, but only at specific times during the season. At least 20 weed species were characterized during the $3 \mathrm{yr}$ study; however, this number is an underestimate, as grasses, small seedlings with less than three true leaves, and thistles were not identified to species level. The most abundant weeds in these systems were common lambsquarters, redroot pigweed, and common waterhemp (Table 4). The chemically intensive treatment had some of the lowest weed abundances observed (Table 4, Fig. 3), although the only significant differences among treatments in seasonal weed abundances occurred in 2006 (the cover crop system had significantly higher weed densities than the other two systems). Cover crops (and the management associated with removing them) suppressed weed populations in two of the three growing seasons to similar levels to those observed in the systems managed exclusively with herbicides. In 2006, when rye was left in the plots throughout the season, greater weed numbers were present in the cover crop system than the other systems (especially after the crop canopy closed). This was surprising, as rye produces allelochemicals known to suppress competition from other plants (Mwaja et al., 1995; Reberg-Horton et al., 2005). But this was also the only year of study when the cover crop was not killed with herbicides, and we believe that these herbicide applications suppressed weeds that were adapted to grow in concert with the cover crops. Weed populations were more abundant in the reduced chemical system over the chemically intensive system in 2005 and 2007, but only in one of the time periods sampled. Specifically, weeds in the reduced chemical system were particularly high just prior to the crop canopy closure and before herbicides were applied in 2005, and after the canopy had closed in 2007 (Fig. 3). The end result is that the reduced chemical treatment produced greater weed abundances during portions of the growing season, but under normal circumstances the timing and abundance of these weed populations in this treatment had minimal effects on soybean profitability when compared to the weed-free, chemically intensive treatment.

There are several ways that producers could increase the profitability of the cover crop system to make this competitive or even superior to the chemically intensive treatment. First, our annual observations always represented the first year of cover crop use. It is common to see a yield drag associated with first-year cover crop use, but in subsequent years yields typically improve (Osborne et al., 2008). Also, we found that managing the cover crop more efficiently (e.g., killing the cover crop entirely prior to soybean establishment) was key to improving yields of the subsequent soybean crop. Although we found mowing to be ineffective and ultimately used herbicides to kill the cover crop in our study, innovative non-chemical technologies such as roller/crimpers offer organically compatible solutions to eliminating cover crops from farmland (Mirsky et al., 2009; Davis, 2010). Although cover cropped conventional soybean yields could feasibly be as profitable as soybeans managed chemically, producers that target the organic market could have even greater profits than chemically managed soybeans due to increased organic premiums. For example, if the cover crop approach was able to earn an organic premium (approximately \$335.76 per t; report NW_GR_113, http://search. ams.usda.gov/mnsearch/mnsearch.aspx), then even the lowest soybean yields from the 2006 cover crop treatment would have been more profitable than the chemical intensive treatment. Suffice it to say that we feel that the cover crop treatment has substantial potential as a long-term, sustainable form of pest management if production can be amended so that yields are improved, largely because of the conservation benefits that this approach has for natural enemies. Natural enemies of soybean aphids save producers billions of dollars every year (Landis et al., 2008), and the increasing reliance on insecticides in corn and soybean systems observed in South Dakota (Fausti et al., in press) and the rest of the United States (Meehan et al., 2011) challenges the ability of these beneficial species to contribute their services to farmers.

\section{Acknowledgments}

This work would not have been possible without the steadfast assistance of Janet Fergen and Eric Beckendorf, and Carson Dinger, Kelly Heitkamp, Mallory Johnson, Matt Jones, Lacey Kruse, Malissa Mayer, and Richard White in collecting and processing the insects and collating the data. Doris Lagos and David Voegtlin helped to identify soybean aphids in tile traps. Emmanuel Opuku assisted with locating historical cost information on the inputs. Max Pravacek assisted in managing the field plots. Beth Choate (USDA-ARS) and Kelley Tilmon (South Dakota State University) provided helpful comments on an earlier draft of this manuscript. Mention of trade names or commercial products in this publication is solely for the purpose of providing specific information and does not imply recommendation or endorsement by the U.S. Department of Agriculture. 
Appendix 1. Cost data. All data in the model was calculated as price or cost per ha. ${ }^{\text {a }}$

\begin{tabular}{|c|c|c|c|c|c|}
\hline \multirow[t]{2}{*}{ Input/output } & & \multicolumn{3}{|l|}{ Price } & \multirow[t]{2}{*}{ Reference } \\
\hline & & 2005 & 2006 & 2007 & \\
\hline \multirow{4}{*}{$\begin{array}{c}\text { Chemical } \\
\text { costs }\end{array}$} & Metolachlor & $\$ 410 \mathrm{~L}^{-1}$ & $\$ 407 \mathrm{~L}^{-1}$ & - & 1 \\
\hline & Glyphosate & $\$ 128 \mathrm{~L}^{-1}$ & $\$ 111 \mathrm{~L}^{-1}$ & $\$ 108 \mathrm{~L}^{-1}$ & 1 \\
\hline & Esfenvalerate & - & $\$ 384 \mathrm{~L}^{-1}$ & - & 1 \\
\hline & $\begin{array}{l}\text { Lambda- } \\
\text { cyhalothrin }\end{array}$ & $\$ 1425 \mathrm{~L}^{-1}$ & $\$ 1459 \mathrm{~L}^{-1}$ & $\$ 1406 \mathrm{~L}^{-1}$ & 2 \\
\hline \multirow[t]{5}{*}{ Seed costs } & $\begin{array}{l}\text { Soybean } \\
\text { seed } \\
\text { (non-GM) }\end{array}$ & $\$ 495 \mathrm{t}^{-1}$ & $\$ 554 \mathrm{t}^{-1}$ & $\$ 882 \mathrm{t}^{-1}$ & 3 \\
\hline & $\begin{array}{l}\text { Soybean } \\
\text { seed (GM) }\end{array}$ & $\$ 1516 \mathrm{t}^{-1}$ & $\$ 1378 \mathrm{t}^{-1}$ & $\$ 1332 \mathrm{t}^{-1}$ & 3 \\
\hline & $\begin{array}{l}\text { Technology } \\
\text { fees }\end{array}$ & $\$ 551 \mathrm{t}^{-1}$ & $\$ 551 \mathrm{t}^{-1}$ & $\$ 551 \mathrm{t}^{-1}$ & 3 \\
\hline & Rye seed & - & $\$ 38.45 \mathrm{ha}^{-1}$ & - & 4 \\
\hline & Oat seed & $34.14 \mathrm{ha}^{-1}$ & - & $34.14 \mathrm{ha}^{-1}$ & 4 \\
\hline \multirow[t]{3}{*}{$\begin{array}{l}\text { Miscellaneous } \\
\text { costs }\end{array}$} & $\begin{array}{l}\text { Cover crop } \\
\text { planting }\end{array}$ & $\$ 19.77$ ha $^{-1}$ & $\$ 22.24 \mathrm{ha}^{-1}$ & $\$ 24.71 \mathrm{ha}^{-1}$ & 3 \\
\hline & Mowing & $\$ 12.36 \mathrm{ha}^{-1}$ & $\$ 13.59 \mathrm{ha}^{-1}$ & $\$ 14.83 \mathrm{ha}^{-1}$ & 3 \\
\hline & $\begin{array}{l}\text { Chemical } \\
\text { application }\end{array}$ & $\$ 12.36 \mathrm{ha}^{-1}$ & $\$ 13.59 \mathrm{ha}^{-1}$ & $\$ 14.83 \mathrm{ha}^{-1}$ & 3 \\
\hline \multicolumn{2}{|c|}{ Soybean yield price } & $\$ 248 \mathrm{t}^{-1}$ & $\$ 277 \mathrm{t}^{-1}$ & $\$ 441 \mathrm{t}^{-1}$ & 5 \\
\hline
\end{tabular}

${ }^{1}$ Agricultural statistics 2005-2008.

${ }^{2}$ AgFirst Farmers Cooperative, Brookings, SD, USA, 57006.

${ }^{3}$ SDSU Extension (field personnel) indicate seed cost twice bean price.

${ }^{4}$ Milborn Seeds, Brookings, SD, USA, 57006.

${ }^{5}$ South Dakota Agriculture 2009, South Dakota Agricultural Statistics Service, Bulletin No. 69, June 2009.

a The text indicates a planting rate of 370,000 seeds per hectare. There are 150,000 soybean seeds per bushel. So it is assumed the application rate on one bushel per acre for the non GM treatment. It is also assumed that the price of non GM soybean seed is twice the market price for a bushel of soybeans. South Dakota State University Cooperative Extension Service provided estimates of GM seed cost and technology fees. Application costs and mowing costs were determined by the number of times an activity was reported.

\section{References}

Andow, D.A., 1991. Vegetational diversity and arthropod population response. Annu. Rev. Entomol. 36, 561-586.

Beckendorf, E.A., Catangui, M.A., Riedell, W.E., 2008. Soybean aphid feeding injury and soybean yield, yield components, and seed composition. Agron. J. 100, 237-246.

Bradshaw, J.D., Rice, M.E., Hill, J.H., 2008. Evaluation of management strategies for bean leaf beetles (Coleoptera: Chrysomelidae) and bean pod mottle virus (Comoviridae) in soybean. J. Econ. Entomol. 101, 1211-1227.

Broad, S.T., Lisson, S.N., Mendham, N.J., 2009. Agronomic and gross margin analysis of an insect pest suppressive broccoli cropping system. Agric. Syst. 102, 41-47.

Brosius, T.R., Higley, L.G., Hunt, T.E., 2007. Population dynamics of soybean aphid and biotic mortality at the edge of its range. J. Econ. Entomol. 100, 1268-1275.

Brown, C.G., Sharkey, M.J., Johnson, D.W., 2003. Bionomics of Scymnus (Pullus) louisianae J. Chapin (Coleoptera: Coccinellidae) as a predator of the soybean aphid, Aphis glycines Matsumura (Homoptera: Aphididae). J. Econ. Entomol. 96, 21-24.

Butler, C.D., O’Neil, R.J., 2008. Voracity and prey preference of insidious flower bug (Hemiptera: Anthocoridae) for immature stages of soybean aphid (Hemiptera: Aphididae) and soybean thrips (Thysanoptera: Thripidae). Environ. Entomol. 37, 964-972.

Byamukama, E., Robertson, A.E., Nutter, F.W.J., 2011. Quantifying the within-field temporal and spatial dynamics of Bean pod mottle virus in soybean. Plant Dis. 95, 126-136.

Clark, A.J., Perry, K.L., 2002. Transmissibility of field isolates of soybean viruses by Aphis glycines. Plant Dis. 86, 1219-1222.

Costamagna, A.C., Landis, D.A., Brewer, M.J., 2008. The role of natural enemy guilds in Aphis glycines suppression. Biol. Control 45, 368-379.

Davis, A.S., 2010. Cover-crop roller-crimper contributes to weed management in notill soybean. Weed Sci. 58, 300-309.

Desneux, N., O'Neil, R.J., 2008. Potential of an alternative prey to disrupt predation of the generalist predator, Orius insidiosus, on the pest aphid, Aphis glycines, via short-term indirect interactions. Bull. Entomol. Res. 98, 631-639.

Desneux, N., O'Neil, R.J., Yoo, H.J.S., 2006. Suppression of population growth of the soybean aphid, Aphis glycines Matsumura, by predators: the identification of a key predator, and the effects of prey dispersion, predator density and temperature. Environ. Entomol. 35, 1342-1349.
Fausti, S.W., McDonald, T.M., Lundgren, J.G., Li, J., Keating, A.R., Catangui, M.A. Insecticide use and crop selection in regions with high GM adoption rates. Renew. Agr. Food Syst., in press.

Fox, T.B., Landis, D.A., Cardoso, F.F., DiFonzo, C.D., 2004. Predators suppress Aphis glycines Matsumura population growth in soybean. Environ. Entomol. 33, 608-618.

Gardiner, M.M., Landis, D.A., Gratton, C., Schmidt, N., O’Neal, M., Mueller, E., Chacon, J., Heimpel, G.E., 2010. Landscape composition influences the activity density of Carabidae and Arachnida in soybean fields. Biol. Control 55, 11-19.

Griffen, M.L., Yeargan, K.V., 2002. Oviposition site selection by the spotted ladybeetle Coleomegilla maculata (Coleoptera: Coccinellidae): choices among plant species. Environ. Entomol. 31, 107-111.

Hammack, L., Pikul Jr., J.L., West, M.S., 2010. Phenology and abundance of bean leaf beetle (Coleoptera: Chrysomelidae) in Eastern South Dakota on alfalfa and soybean relative to tillage, fertilization, and yield. Environ. Entomol. 39, 727-737.

Hammond, R.B., Jeffers, D.L., 1990. Potato leafhopper (Homoptera: Cicadellidae) populations on soybean intercropped into winter wheat. Environ. Entomol. 19, 1810-1819.

Harwood, J.D., Yoo, H.J.S., Rowley, D.L., Greenstone, M.H., O'Neil, R.J., 2009. Differential impact of adults and nymphs of a generalist predator on an exotic invasive pest demonstrated by molecular gut-content analysis. Biol. Invasions 11, 895-903.

Heap, I., 2012. International Survey of Herbicide Resistant Weeds. www.weed science.org.

Hodgson, E.W., Koch, R.L., Ragsdale, D.W., 2005. Pan trapping for soybean aphid (Homoptera: Aphididae) in Minnesota soybean fields. J. Entomol. Sci. 40, 409-419.

Irwin, M.E., Goodman, R.M., 1981. Ecology and control of soybean mosaic virus. In: Maramorosch, K., Harris, K.F. (Eds.), Plant Diseases and Their Vectors: Ecology and Epidemiology. Academic Press, New York, pp. 181-222.

Johnson, K.D., O’Neal, M.E., Bradshaw, J.D., Rice, M.E., 2008. Is preventative, concurrent management of the soybean aphid (Hemiptera: Aphididae) and bean leaf beetle (Coleoptera: Chrysomelidae) possible? J. Econ. Entomol. 101, 801-809.

Koch, R.L., Porter, P.M., Harbur, M.M., Abrahamson, M.D., Wyckhuys, K.A.G., Ragsdale, D.W., Koch, K., Sezen, Z., Heimpel, G.E., 2012. Response of soybean insects to an autumn-seeded rye cover crop. Environ. Entomol. 41, 750-760.

Landis, D.A., Gardiner, M.M., van der Werf, W., Swinton, S.M., 2008. Increasing corn for biofuel production reduces biocontrol services in agricultural landscapes. Proc. Natl. Acad. Sci. U S A 105, 20552-20557.

Letourneau, D.K., Armbrecht, I., Rivera, B.S., Lerma, J.M., Carmona, E.J., Daza, M.C., Escobar, S., Galindo, V., Gutiérrez, C., López, S.D., Mejía, J.L., Rangel, A.M.A., Rangel, J.H., Rivera, L., Saavedra, C.A., Torres, A.M., Trujillo, A.R., 2011. Does plant diversity benefit agroecosystems? A synthetic review. Ecol. Appl. 21, 9-21.

Liu, J., Wu, K., Hopper, K.R., Zhao, K., 2004. Population dynamics of Aphis glycines (Homoptera: Aphididae) and its natural enemies in soybean in northern China. Ann. Entomol. Soc. Am. 97, 235-239.

Lundgren, J.G., Fergen, J.K., 2010. The effects of a winter cover crop on Diabrotica virgifera (Coleoptera: Chrysomelidae) populations and beneficial arthropod communities in no-till maize. Environ. Entomol. 39, 1816-1828.

Lundgren, J.G., Fergen, J.K., 2011. Enhancing predation of a subterranean insect pest: a conservation benefit of winter vegetation in agroecosystems. Appl. Soil Ecol. 51, 9-16.

Lundgren, J.G., Fergen, J.K., Riedell, W.E., 2008. The influence of plant anatomy on oviposition and reproductive success of the omnivorous bug, Orius insidiosus. Anim. Behav. 75, 1495-1502.

Lundgren, J.G., Gassmann, A.J., Bernal, J.S., Duan, J.J., Ruberson, J.R., 2009a. Ecological compatibility of GM crops and biological control. Crop Prot. 28, 1017-1030.

Lundgren, J.G., Riedell, W.E., 2008. Soybean nitrogen relations and root characteristics after Cerotoma trifurcata (Coleoptera: Chrysomelidae) larval feeding injury. J. Entomol. Sci. 43, 107-116.

Lundgren, J.G., Shaw, J.T., Zaborski, E.R., Eastman, C.E., 2006. The influence of organic transition systems on beneficial ground-dwelling arthropods and predation of insects and weed seeds. Renew. Agr. Food Syst. 21, 227-237.

Lundgren, J.G., Wyckhuys, K.A.G., Desneux, N., 2009b. Population responses by Orius insidiosus to vegetational diversity. BioControl 54, 135-142.

Mabry, T.R., Hobbs, H.A., Steinlage, T.A., Johnson, B.B., Pedersen, W.L., Spencer, J.L., Levine, E., Isard, S.A., Domier, L.L., Hartman, G.L., 2003. Distribution of leaffeeding beetles and Bean pod mottle virus (BPMV) in Illinois and transmission of BPMV in soybean. Plant Dis. 87, 1221-1225.

Macedo, T.B., Bastos, C.S., Higley, L.G., Ostlie, K.R., Madhavan, S., 2003. Photosynthetic responses of soybean to soybean aphid (Homoptera: Aphididae) injury. J. Econ. Entomol. 96, 188-193.

Marvier, M., McCreedy, C., Regetz, J., Kareiva, P., 2007. A meta-analysis of effects of Bt cotton and maize on nontarget invertebrates. Science 316, 1475-1477.

Meehan, T.D., Werling, B.P., Landis, D.A., Gratton, C., 2011. Agricultural landscape simplification and insecticide use in the Midwestern United States. Proc. Natl. Acad. Sci. U S A 101, 11500-11505.

Miklasiewicz, T.J., Hammond, R.B., 2001. Density of potato leafhopper (Homoptera: Cicadellidae) in response to soybean-wheat cropping systems. Environ. Entomol. 30, 204-214.

Mirsky, S.B., Curran, W.S., Mortensen, D.A., Ryan, M.R., Shumway, D.L., 2009. Control of cereal rye with a roller/crimper as influenced by cover crop phenology. Agron. J. 101, 1589-1596. 
Mortensen, D.A., Egan, J.F., Maxwell, B.D., Ryan, M.R., Smith, R.G., 2012. Navigating a critical juncture for sustainable weed management. BioScience $62,75-84$.

Musser, F.R., Knighten, K.S., Smith, J.F., Catchot, A.L., 2012. Pyrethroid insecticide tolerance in bean leaf beetle, Certoma trifurcata, in the Mississippi Delta. Pest Manag. Sci. 68, 658-662.

Mwaja, V.N., Masiunas, J.B., Weston, L.A., 1995. Effects of fertility on biomass, phytotoxicity, and allelochemical content of cereal rye. J. Chem. Ecol. 21, 81-96.

Ohnesorg, W.J., Johnson, K.D., O'Neal, M.E., 2009. Impact of reduced-risk insecticides on soybean aphid and associated natural enemies. J. Econ. Entomol. 102, 1816-1826.

Osborne, S.L., Schumacher, T.E., Humburg, D.S., 2008. Evaluation of cover crops to increase corn emergence, yield and field trafficability. Agric. J. 3, 397-400.

Ragsdale, D.W., Landis, D.A., Brodeur, J., Heimpel, G.E., Desneux, N., 2011. Ecology and management of the soybean aphid in North America. Annu. Rev. Entomol. 56, 378-399.

Ragsdale, D.W., McCornack, B.P., Venette, R.C., Potter, B.D., MacRae, I.V. Hodgson, E.W., O’Neal, M.E., Johnson, K.D., O'Neil, R.J., DiFonzo, C.D., Hunt, T.E., Glogoza, P.A., Cullen, E.M., 2007. Economic threshold for soybean aphid (Hemiptera: Aphididae). J. Econ. Entomol. 100, 1258-1267.

Ragsdale, D.W., Voegtlin, D.J., O'Neil, R.J., 2004. Soybean aphid biology in North America. Ann. Entomol. Soc. Am. 97, 204-208.

Reberg-Horton, S.C., Burton, J.D., Danehower, D.A., Ma, G.Y., Monks, D.W., Murphy, J.P., Ranells, N.N., Williamson, J.D., Creamer, N.G., 2005. Changes over time in the allelochemical content of ten cultivars of rye (Secale cereale L.). J. Chem. Ecol. 31, 179-193.

Rhainds, M., Roy, M., Daigle, G., Brodeur, J., 2007. Toward management guidelines for the soybean aphid in Quebec. I. Feeding damage in relationship to seasonality of infestation and incidence of native predators. Can. Entomol. 139, $728-741$.

Riedell, W.E., Catangui, M.A., 2006. Greenhouse studies of soybean aphid (Hemiptera: Aphididae) eff ects on plant growth, seed yield and composition. J. Agr. Urban Entomol. 23, 225-235.

Riedell, W.E., Catangui, M.A., Beckendorf, E.A., 2009. Nitrogen fixation, ureide, and nitrate accumulation responses to soybean aphid injury in Glycine max. J. Plant Nutr. 32, 1674-1686.
Riedell, W.E., Osborne, S.L., Lundgren, J.G., Pikul Jr., J.L., 2011. Nitrogen fertilizer management effects on soybean nitrogren components and bean leaf beetle populations. Agron. J. 103, 1432-1440.

Rutledge, C.E., O'Neil, R.J., 2005. Orius insidiosus (Say) as a predator of the soybean aphid, Aphis glycines Matsumura. Biol. Control 33, 56-64.

Rutledge, C.E., O'Neil, R.J., Fox, T.B., Landis, D.A., 2004. Soybean aphid predators and their use in integrated pest management. Ann. Entomol. Soc. Am. 97, 240-248.

Schmidt, N.P., O'Neal, M.E., Dixon, P.M., 2008. Aphidophagous predators in Iowa soybean: a community comparison across multiple years and sampling methods. Ann. Entomol. Soc. Am. 101, 341-350.

Schmidt, N.P., O'Neal, M.E., Singer, J.W., 2007. Alfalfa living mulch advances biological control of soybean aphid. Environ. Entomol. 36, 416-424.

Seagraves, M.P., Lundgren, J.G., 2010. Oviposition response by Orius insidiosus (Hemiptera: Anthocoridae) to plant and prey availability. Biol. Control 55, 174-177.

Seagraves, M.P., Lundgren, J.G., 2012. Effects of neonicotinoid seed treatments on soybean aphid and its natural enemies. J. Pest Sci. 85, 125-132.

Smith, A.N., Reberg-Horton, S.C., Place, G.T., Meijer, A.D., Arellano, C., Mueller, J.P. 2011. Rolled rye mulch for weed suppression in organic no-tillage soybeans. Weed Sci. 59, 224-231.

Tillman, G., Schomberg, H., Phatak, S., Mullinix, B., Lachnicht, S., Timper, P. Olson, D.M., 2004. Influence of cover crops on insect pests and predators in conservation tillage cotton. J. Econ. Entomol. 97, 1217-1232.

Toepfer, S., Haye, T., Erlandson, M., Goettel, M., Lundgren, J.G., Kleespies, R.G Weber, D.C., Cabrera Walsh, G., Peters, A., Ehlers, R.-U., Strasser, H., Moore, D., Keller, S., Vidal, S., Kuhlmann, U., 2009. A review of the natural enemies of beetles in the subtribe Diabroticina (Coleoptera: Chrysomelidae): implications for sustainable pest management. Biocontrol Sci. Technol. 19, 1-65.

White, H., 1980. A heteroskedasticity-consistent covariance matrix estimator and a direct test for heteroskedasticity. Econometrica 48, 817-838.

Wolfenbarger, L.L., Naranjo, S.E., Lundgren, J.G., Bitzer, R.J., Watrud, L.S., 2008. Bt crop effects on functional guilds of non-target arthropods: a meta-analysis. PLoS One 3, e2118. http://dx.doi.org/10.1371/journal.pone.0002118.

Yoo, H.J.S., O'Neil, R.J., 2009. Temporal relationships between the generalist predator, Orius insidiosus, and its two major prey in soybean. Biol. Control 48, $168-180$. 